\author{
UNIVERSIDADE DE SÃO PAULO \\ FACULDADE DE ODONTOLOGIA DE BAURU
}

CAREN AUGUSTINHO DO NASCIMENTO

Effect of sweetener containing Stevia on the development of dental caries in enamel and dentin under a microcosm biofilm model

Efeito de adoçante contendo Stevia no desenvolvimento da cárie dentária em esmalte e dentina sob um modelo de biofilme de microcosmo 



\title{
Effect of sweetener containing Stevia on the development of dental caries in enamel and dentin under a microcosm biofilm model
}

\section{Efeito de adoçante contendo Stevia no desenvolvimento da cárie dentária em esmalte e dentina sob um modelo de biofilme de microcosmo}

\begin{abstract}
Dissertation presented to the Bauru School of Dentistry of the University of São Paulo to obtain the degree of Master in Science in the Applied Dental Science Program, Stomatology and Oral Biology concentration area.

Supervisor: Prof. Dr. Ana Carolina Magalhães

Dissertação apresentada à Faculdade de Odontologia de Bauru da Universidade de São Paulo para obtenção do título de Mestre em Ciências no Programa de Ciências Odontológicas Aplicadas, área de concentração Estomatologia e Biologia Oral. Orientadora: Profa. Dra. Ana Carolina Magalhães
\end{abstract}

BAURU 
Nascimento, Caren Augustinho do

So89e Effect of sweetener containing Stevia on the development of dental caries in enamel and dentin under a microcosm biofilm model/ Caren Augustinho do Nascimento. - Bauru, 2021.

75 p.: il. ; $31 \mathrm{~cm}$.

Dissertação (Mestrado) - Faculdade de Odontologia de Bauru. Universidade de São Paulo

Autorizo, exclusivamente para fins acadêmicos e científicos, a reprodução total ou parcial desta dissertação/tese, por processos fotocopiadores e outros meios eletrônicos.

Assinatura:

Data:

Comitê de Ética da FOB-USP

Protocolo n: 12647819.5 .0000 .5417

Data: $14 / 05 / 2019$ 


\section{ERRATA}



FOLHA DE APROVAÇÃO 



\section{DEDICATÓRIA}

\section{$\mathcal{A}$ Deus,}

Por ser o autor do meu destino, por me abençoar com saúde e sabedoría, por ser o meu guia e estar sempre presente em minha vida. Sem Ele, eu não estaria aquí.

"A tua palavra é làmpada que ilumina os meus passos e luz que clareia o meu caminho."

Salmos 119:105

À minha família,

Em especial à minha mãe Sílvana e ao meu pai Carlos, por todo amor, amizade, apoio e companheirismo. Sempre me deram o suporte necessário e torceram muito pelas minhas conquistas, acreditando que seria possivel.

"Honra teu pai e tua mãe, a fim de que tenhas vida longa na terra que o Senhor, o teu Deus, te dá." Exxodo 20:12

\section{Aos professores,}

Por serem amigos e companheiros, sempre dispostos a orientar e ensinar. Em especial à professora Ana Carolina Magalhães, que acreditou no meu sonho de fazer mestrado logo após a graduação, me ensinou tudo o que foi necessário para conduzir o projeto de pesquisa e sempre esteve presente em todas as dificuldades.

"Professores Grithantes ensinam para uma profissão. Professores fascinantes ensinam para a vida." Augusto Cury 



\section{AGRADECIMENTOS}

\section{A Deus,}

Pelo dom da vida, saúde e sabedoria. Agradeço por me permitir nascer em uma família maravilhosa e me proteger. Obrigada pelo caminho abençoado e pelas pessoas que estão presentes.

\section{Aos meus pais Silvana e Carlos,}

Agradeço por estarem sempre presentes, me orientando, ensinando o melhor caminho e torcendo com muito amor por cada conquista. Obrigada por me proporcionar a educação e investir em meus conhecimentos. Vocês são os maiores exemplos de melhores amigos que eu poderia ter. Essa conquista é nossa!

\section{Ao meu irmão Caio,}

Agradeço por estar sempre por perto, cuidando, aconselhando e ajudando em todos os momentos que eu preciso. Obrigada por ser o melhor irmão e padrinho.

\section{À minha avó Nely,}

Agradeço pela torcida, apoio e por acreditar no meu potencial. Quando as coisas ficaram difíceis, você estava presente para orientar e aconselhar. Obrigada por se preocupar com a minha felicidade e estar sempre ao meu lado.

Ao meu bem Giovanne,

Agradeço por ser o meu melhor amigo e estar presente em mais uma etapa/conquista da minha vida. Obrigada pelo carinho, companheirismo e por estar sempre disposto a ajudar.

Aos queridos amigos de iniciação cientifica, mestrado, doutorado e pós doutorado,

Obrigada por me receberem com carinho na FOB/USP e pelos ensinamentos. Agradeço as minhas queridas alunas de IC Carolina e Rafaela, ao meu amigo de mestrado Ricardo e as co-orientadoras Aline e Beatriz, por participarem de todas as fases do meu mestrado, por serem amigos e companheiros. Estudar e aprender com vocês tornou a caminhada mais leve e feliz. 

As minhas amigas técnicas do laboratório Larissa e Thelma,

Agradeço por estarem sempre presentes no laboratório, dispostas a ensinar e orientar com carinho. Obrigada pela amizade, por toda ajuda e cuidado.

\section{Aos amigos e funcionários do Centro Integrado de Pesquisa - CIP,}

Agradeço por me receberem bem e pelos ensinamentos, em especial ao Marcelo e a Márcia, que passamos anos juntos, agendando ensaios e conduzindo experimentos.

Aos professores da Disciplina de Bioquímica, Prof ${ }^{a}$ Dra Ana Carolina Magalhães, Prof. Dr. Rodrigo Cardoso de Oliveira e Prof ${ }^{a}$ Dra Marília Afonso Rabelo Buzalaf,

Agradeço por todas as aulas, seminários e ensinamentos. Obrigada por compartilharem o conhecimento da forma mais didática possível, vocês fazem toda a diferença. Cada momento vivenciado foi muito importante para o meu crescimento.

\section{À secretária do Departamento Dalva Ribeiro de Oliveira,}

Agradeço por estar sempre presente e disposta a ajudar com dedicação e carinho. Obrigada por me ajudar e escolher as melhores disciplinas para cumprir os créditos do mestrado. Obrigada por ser, além de secretaria, amiga.

\section{À Faculdade de Odontologia de Bauru- FOB/USP,}

Agradeço pela oportunidade de realizar o meu sonho de pós-graduação, em nível de Mestrado, na FOB/USP. Obrigada pelo suporte, pela estrutura e por tornar essa experiência única.

A todos os funcionários da FOB-USP que colaboraram de forma direta ou indireta para o desenvolvimento deste trabalho, em especial aos guardas da portaria, que sempre me receberam bem e com um sorriso no rosto, inclusive nos finais de semana chuvosos, em que precisavam abrir o portão as 7h da manhã. Agradeço por tornar a minha trajetória tranquila e feliz.

\section{À Fundação de Amparo à Pesquisa do Estado de São Paulo (FAPESP),}

Agradeço pela concessão da minha bolsa de Mestrado, importante para meu aprimoramento profissional e pessoal (Processo 2019/02018-0). 

"Agradeço todas as dificuldades que enfrenteí; não fosse por elas, eu não teria saido do lugar. As facilidades nos impedem de caminhar. Mesmo as críticas nos auxíliam muito." Chico Xavier 



\section{RESUMO}

\section{Efeito de adoçante contendo Stevia no desenvolvimento da cárie dentária em esmalte e dentina sob um modelo de biofilme de microcosmo}

Este estudo comparou o efeito de um adoçante comercial e puro contendo Stevia ao do aspartame (comercial e puro), sacarose (açúcar comum), xilitol (adoçante natural conhecido por ser anti-cariogênico) no desenvolvimento de cárie dentária em um modelo de biofilme microcosmo formado sobre o esmalte e a dentina. Para isso, foram preparadas 228 amostras de esmalte bovino e 228 amostras de dentina radicular bovina ( $4 \mathrm{~mm} \times 4 \mathrm{~mm}$ ). Em placas de 24 poços, cada amostra de esmalte ou dentina foi exposta a $1,5 \mathrm{~mL}$ de inóculo (saliva-glicerol humana + saliva de McBain, 1:50), por $8 \mathrm{~h}$. Após as $8 \mathrm{~h}$ iniciais, o inóculo foi retirado, as amostras foram lavadas com PBS (5 s), receberam $1,5 \mathrm{~mL}$ de meio fresco (saliva artificial McBain) por $16 \mathrm{~h}$, completando as $24 \mathrm{~h}$ iniciais. Do $2^{\circ}$ ao $5^{\circ}$ dia de cultivo do biofilme, as amostras foram expostas diariamente à saliva de McBain suplementada com $0,2 \%$ dos respectivos adoçantes/açúcar: Stevia, aspartame (ambos na forma pura ou comercial, marca Finn), xilitol, sacarose e saliva (McBain) controle sem suplementação ( $n=3 /$ placa, quadriplicada biológica). O cultivo foi realizado a $5 \% \mathrm{CO}_{2}$ e 37으. A produção de ácido lático ( $\mathrm{g} / \mathrm{L}$ ) e as unidades formadoras de colônia (UFC) para microrganismos totais, lactobacilos totais, estreptococos totais e Streptococcus mutans/ S. sobrinus $\left(\log _{10} \mathrm{UFC} / \mathrm{mL}\right.$ ) foram quantificadas no biofilme. O grau de desmineralização dentária foi analisado por meio da microrradiografia transversalTMR. Os dados foram comparados estatisticamente (Kruskal-Wallis/Dunn, $p<0,05$ ). $\mathrm{Na}$ análise do lactato, os adoçantes stevia pura, aspartame puro, xilitol e controle não diferiram entre si, reduzindo em $92 \%$ a produção deste ácido. Os grupos stevia finn, aspartame finn e sacarose apresentaram maior produção de ácido lático, sendo similares entre si $(0,47 \pm 0,14,0,43 \pm 0,10,0,44 \pm 0,13 \mathrm{~g} / \mathrm{L}$ para o esmalte; 0,69 \pm $0,19,0,65 \pm 0,11,0,67 \pm 0,24 \mathrm{~g} / \mathrm{L}$ para a dentina, respectivamente, $p<0,0001)$. Em relação à contagem de UFCs para lactobacilos totais e $S$. mutans/ $S$. sobrinus, os grupos xilitol e controle não apresentaram crescimento de colônias sobre o esmalte. As espécies cresceram sob exposição a stevia finn, aspartame finn e sacarose no esmalte e dentina $\left(5,69 \pm 0,44,5,69 \pm 0,82,5,75 \pm 0,60 \log _{10}\right.$ UFC lactobacilos totais $/ \mathrm{mL}$ de; $7,57 \pm 0,37,7,61 \pm 0,64,7,49 \pm 0,41 \log _{10}$ UFC $S$. mutans/mL para esmalte; $0,00 \pm 3,98,5,30 \pm 5,30,5,30 \pm 0,15 \log _{10}$ UFC lactobacilos totais/mL; $7,83 \pm 0,36$, 

$7,87 \pm 0,18 ; 7,78 \pm 0,31 \log _{10}$ UFC $S$. mutans $/ \mathrm{mL}$ para a dentina, respectivamente). A desmineralização do esmalte e da dentina foi significativamente reduzida para os grupos xilitol, controle, stevia pura e aspartame puro (aproximadamente 85\% e 83\% de redução, respectivamente) em comparação com stevia finn, aspartame finn e sacarose que, por sua vez, não diferiram entre si $(\Delta Z: 3084,7 \pm 834,3,3174,7 \pm$ $603,1,2913,7 \pm 646,7$ vol\%.um para o esmalte e $3945,7 \pm 689,7,3626,8 \pm 617,3$, $3543,3 \pm 432,5$ vol\%. mm para a dentina, respectivamente). Em conclusão, adoçantes comerciais à base de stevia e aspartame (marca Finn) mostraram-se tão cariogênicos quanto à sacarose neste modelo experimental, o que se deve aos outros componentes destes adoçantes, uma vez que as formas puras não foram cariogênicas.

Palavras-chave: açúcar, adoçante, biofilme dentário, cárie dentária, dentina, esmalte. 



\section{ABSTRACT \\ Effect of sweetener containing Stevia on the development of dental caries in enamel and dentin under a microcosm biofilm model}

This study compared the effect of a commercial and pure sweetener containing Stevia to that of aspartame (commercial and pure), sucrose (common sugar), xylitol (a natural sweetener known to be anti-cariogenic) on the development of dental caries in a microcosm biofilm model formed over enamel and dentin. For this, 228 bovine enamel and 228 samples of bovine root dentin samples $(4 \mathrm{~mm} \times 4 \mathrm{~mm}$ ) were prepared. In 24-well plates, each enamel or dentin sample was exposed to $1.5 \mathrm{~mL}$ of inoculum (human saliva-glycerol + McBain saliva, 1:50), for $8 \mathrm{~h}$. After the initial $8 \mathrm{~h}$, the inoculum was removed, the samples were washed with PBS $(5 \mathrm{~s})$, received 1.5 $\mathrm{mL}$ of fresh medium (McBain artificial saliva) for $16 \mathrm{~h}$, completing the initial $24 \mathrm{~h}$. From the $2^{\text {nd }}$ to the $5^{\text {th }}$ day of biofilm cultivation, the samples were exposed daily to McBain saliva supplemented with $0.2 \%$ of the respective sweeteners /sugar: Stevia, aspartame (both in pure or commercial form, Finn brand), xylitol, sucrose and control saliva (McBain) without supplementation ( $n=3$ /plate, biological quadruplicate). The cultivation was carried out at $5 \% \mathrm{CO}_{2}$ and $37^{\circ} \mathrm{C}$. The production of lactic acid $(\mathrm{g} / \mathrm{L})$ and colony-forming units (CFU) for total microorganisms, total lactobacilli, total streptococci and Streptococcus mutans/ S. sobrinus ( $\log _{10} \mathrm{CFU} / \mathrm{mL}$ ) were quantified in the biofilm. The degree of dental demineralization was analyzed using transverse microradiography-TMR. The data were compared statistically (Kruskal-Wallis / Dunn, $p<0.05)$. In the lactate analysis, the sweeteners pure stevia, pure aspartame, xylitol and control did not differ, reducing by $92 \%$ the production of this acid. The groups stevia finn, aspartame finn and sucrose showed higher production of lactic acid, being similar to each other $(0.47 \pm 0.14,0.43 \pm 0.10,0.44 \pm 0.13 \mathrm{~g} / \mathrm{L}$ for enamel; 0.69 $\pm 0.19,0.65 \pm 0.11,0.67 \pm 0.24 \mathrm{~g} / \mathrm{L}$ for dentin, respectively, $\mathrm{p}<0.0001)$. Regarding the CFU counting for total lactobacilli and $S$. mutans/S. sobrinus, xylitol and control groups did not show colony growth on enamel. The species grew under exposure to stevia finn, aspartame finn and sucrose in enamel and dentin (5.69 $\pm 0.44,5.69 \pm$ $0.82,5.75 \pm 0.60 \log _{10} \mathrm{CFU}$ total lactobacilli/mL; $7.57 \pm 0.37,7.61 \pm 0.64,7.49 \pm 0.41$ $\log _{10}$ CFU S. mutans $/ \mathrm{mL} ; 0.00 \pm 3.98,5.30 \pm 5.30,5.30 \pm 0.15 \log _{10}$ CFU total lactobacilli/mL; $7.83 \pm 0.36,7.87 \pm 0.18 ; 7.78 \pm 0.31 \log _{10}$ CFU S. mutans $/ \mathrm{mL}$ for enamel and dentin, respectively). Enamel and dentin demineralization was 

significantly reduced for the xylitol, control, pure stevia and pure aspartame groups (approximately $85 \%$ and $83 \%$ reduction, respectively) compared to stevia finn, aspartame finn and sucrose which, in turn, did not differ from each other $(\Delta Z$ : $3084.67 \pm 834.26,3174.67 \pm 603.10,2913.67 \pm 646.69$ vol\%. $\mu \mathrm{m}$ for enamel and $3945.67 \pm 689.69,3626.79 \pm 617.26,3543.33 \pm 432.50$ vol\%. $\mu$ m for dentin). In conclusion, commercial sweeteners based on stevia and aspartame (Finn brand) proved to be as cariogenic as sucrose in this experimental model, which is due to the other components of these sweeteners, since the pure forms were not cariogenic.

Keywords: dental biofilm, dental cavity, dentin, enamel, sugar, sweetener. 



\section{LISTA DE FIGURAS}

Figura 1 - Representative images of the experimental protocol

Figura 2 - Box plot of lactic acid production analysis of the microcosm biofilm on enamel samples $(\mathrm{g} / \mathrm{L})$

Figura 3 - Representative images of TMR for enamel: A - stevia finn, B - pure stevia, C - aspartame finn, D - pure aspartame, E - sucrose, F xylitol, G - control

Figura 4 - Box plot of lactic acid production analysis of the microcosm biofilm on dentin samples $(\mathrm{g} / \mathrm{L})$

Figura 5 - Representative images of TMR for dentin: A - stevia finn, B - pure stevia, C - aspartame finn, D - pure aspartame, E - sucrose, F xylitol, G - control 



\section{LISTA DE TABELAS}

Tabela 1 - Composition of sweeteners

Tabela 2 - CFU counting $\log _{10} / \mathrm{mL}$ [median (interquartile range)] for total MØ, total lactobacilli, total streptococci and S. mutans/S. sobrinus in the microcosm biofilm formed on the enamel and exposed to different sugars /sweeteners

Tabela 3 - TMR analysis of the enamel samples .40

Tabela 4 - CFU counting $\log _{10} / \mathrm{mL}$ [median (interquartile range)] for total MØ, total lactobacilli, total streptococci and S. mutans/S. sobrinus in the microcosm biofilm formed on the dentin and exposed to different sugars /sweeteners

Tabela 5 - TMR analysis of the dentin samples. 



\section{LISTA DE ABREVIATURA E SIGLAS}

\begin{tabular}{|c|c|}
\hline CCD & camera canon \\
\hline CFU & colony forming units \\
\hline $\mathrm{cm}$ & Centimeters \\
\hline$\Delta Z$ & integrated mineral loss \\
\hline DMFT & decayed, missing, filled teeth \\
\hline EPS & extracellular polysaccharide \\
\hline $\mathrm{G}$ & gram \\
\hline $\mathrm{kV}$ & kilovolts \\
\hline$L$ & liter \\
\hline Ld & lesion depth \\
\hline $\mathrm{mA}$ & milliampere \\
\hline Min & minutes \\
\hline $\mathrm{mL}$ & milliliter \\
\hline $\mathrm{Nm}$ & nanometer \\
\hline PBS & phosphate-buffered saline \\
\hline $\mathrm{pH}$ & hydrogen potential \\
\hline $\mathrm{R}$ & average mineral loss \\
\hline $\mathrm{Ra}$ & arithmetic roughness \\
\hline S & seconds \\
\hline TMR & transverse microradiography \\
\hline$\mu L$ & microliters \\
\hline Vol\% & Percentage of volume \\
\hline WHO & World Health Organization \\
\hline$\mu \mathrm{m}$ & micrometer \\
\hline
\end{tabular}





\section{SUMÁRIO}

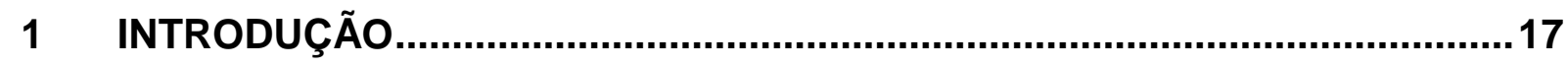

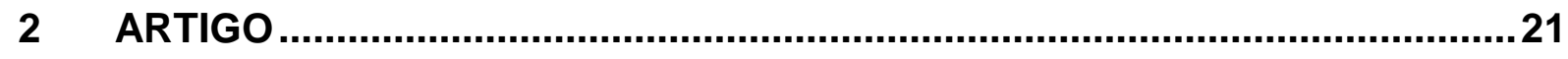

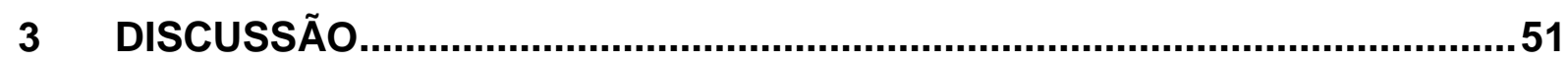

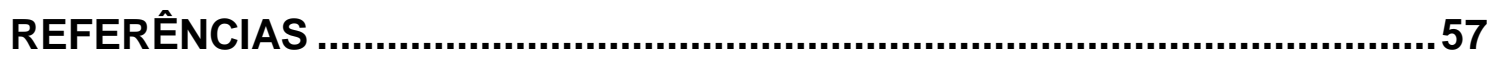

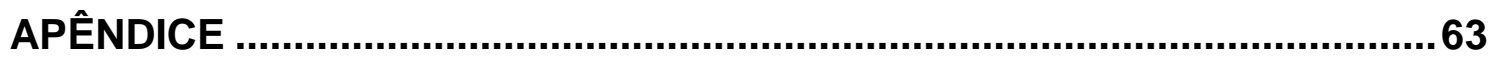

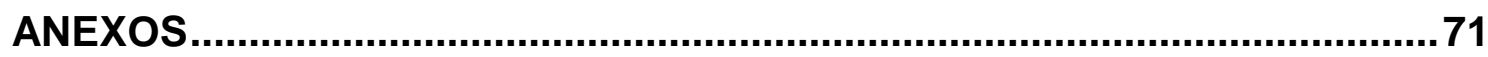



1 INTRODUCTION 



\section{INTRODUCTION}

Dental caries is a multifactorial oral disease highly impacting for the affected person, caused by a biofilm in disbiose, rich in acidogenic, aciduric and EPS (extracellular polysaccharide) producer microorganisms. These microorganisms are capable of metabolizing different types of sugar, mainly sucrose from the diet, forming acids that alter the biofilm $\mathrm{pH}$ and cause tooth demineralization (Keyes, 1960; Bowen, 2002; Marsh et al., 2011; Pitts et al., 2017; Ayoub et al., 2020).

Considering the relationship between dental caries and socioeconomic condition, it is obvious to infer that the consumption of common sugar (sucrose) is highly related to the disease, not only because it is low cost and easy access by the population, but also because bacteria can metabolize it easily. In addition, sucrose is the main substrate for the action of the glycosyltransferase enzyme for production of EPS, which is an important virulence factor for cariogenic bacteria (Paes-Leme et al., 2006; Ccahuana-Vásquez et al., 2007; Li et al., 2020). Accordingly, the World Health Organization (WHO) has recommended that the consumption of added sugar should not exceed more than $5 \%$ of the total energy consumed (around $10 \mathrm{~kg} / \mathrm{year}$ ), so that the number of DMFT is less than 3 in 12 years old children (Moyhinan, 2016; Moynihan \& Miller, 2020).

To replace common sugar, non-caloric sweeteners have been used by $28 \%$ of the population, in order to control obesity and diabetes mellitus (Jayalath et al., 2015; Azad et al., 2016; Manios et al., 2020). Sweeteners can be from natural (stevia) or synthetic origin (aspartame, acesulfame, sodium cyclamate, sucralose). In general, they present high sweetness (greater than sucrose itself). However, there is no evidence about the beneficial effects (control of obesity and diabetes) as well as about the side effects (cancer, headache and others) induced by the frequent consume of sweeteners (Lohner et al., 2017; Nichol et al., 2018; Santos et al., 2018). With respect to dental caries, few studies have shown that non-caloric sweeteners seem to be inert or at least not as cariogenic as sucrose (Giacaman et al., 2013; Giacaman, 2018). 
Among the sweeteners, Stevia rebaudiana Bertoni, belonging to the Asteraceae family, is native from South America. Stevia leaves contain steviol glycosides, including stevioside, rebaudioside (A to F), steviolbioside and isosteviol, which are responsible for the sweet taste of the plant and have commercial value worldwide as a sugar substitute in food, beverages and medicines. In addition to its value as a sweetener, stevia and its glycosides have therapeutic effects against several diseases, such as cancer, diabetes mellitus, hypertension, inflammation, cystic fibrosis, obesity and tooth decay (Momtazi-Borojeni et al., 2017). Few studies have evaluated the effect of stevia on the development of cariogenic biofilm and/or of carious lesions, with inconclusive results regarding its anti-caries potential (Giacaman et al., 2013; Ma \& Blanksma, 2015; Ferrazzano et al., 2015; Kishta et al., 2016; Escobar et al., 2020). There is still a lack of evidence about its safety and benefits, which enable a safer recommendation of Stevia (Samuel et al., 2018).

Considering that obesity is associated with dental caries (Tinanoff \& Holt, 2017; Marro et al., 2021), due to the behavioral nature and dependency of sugar consumption for both diseases, and that the population have replaced common sugar by non-caloric sweeteners, it is necessary to know their anti-caries potential. Therefore, the aim of the work was to compare the effect of sweetener containing stevia (natural sweetener) to that with aspartame (synthetic sweetener), sucrose (common sugar) and xylitol (natural sweetener) on the development of dental caries in a microcosm biofilm model formed on enamel and dentin. 
2 ARTICLE 



\section{ARTICLE}

Article formatted according to Caries Research Guidelines. 
1 Effect of sweetener containing Stevia on the development of dental caries in

2 enamel and dentin under a microcosm biofilm model

3 Nascimento $C A^{1}, \operatorname{Kim} \mathrm{RR}^{1}$, Ferrari $\mathrm{CR}^{1}$, Souza $\mathrm{BM}^{1}$, Braga $\mathrm{AS}^{1}$, Magalhães $A C^{1 *}$

4

$5{ }^{1}$ Department of Biological Sciences, Bauru School of Dentistry, University of São

6 Paulo, Bauru, SP, Brazil.

7

8 Short title: Effect of sweetener containing Stevia on dental caries

9

10 *Corresponding author:

11 Department of Biological Sciences

12 Bauru School of Dentistry - University of São Paulo

13 Al. Octávio Pinheiro Brisolla, 9-75

14 Bauru-SP, Zip code: 17012-901, Brazil

15 Phone/Fax. + 551432358497

16 E-mail: acm@usp.br

17 Number of Tables: 5

18 Number of Figures: 5

19 Word count: 3,469

20 Key words: dental biofilm, dental cavity, dentin, enamel, sugar, sweetener. 


\section{Abstract}

This study compared the effect of a commercial and pure sweetener containing stevia to that of aspartame (commercial and pure), sucrose (common sugar), xylitol (natural sweetener) on the development of dental caries in a microcosm biofilm model. For this, 228 bovine enamel and 228 root dentin $(4 \mathrm{~mm} \times 4 \mathrm{~mm})$ were exposed to microcosm biofilm model using human saliva. From the $2^{\text {nd }}$ to the $5^{\text {th }}$ day of biofilm cultivation, the samples were exposed daily to McBain saliva supplemented with $0.2 \%$ of the respective sweeteners/sugar, under $5 \% \mathrm{CO}_{2}$ and $37^{\circ} \mathrm{C}$. The lactic acid $(\mathrm{g} / \mathrm{L})$ and the colony-forming units for total microorganisms, total lactobacilli, total streptococci and Streptococcus mutans/ S. sobrinus $\left(\log _{10} \mathrm{CFU} / \mathrm{mL}\right)$ were quantified. The demineralization was analyzed by TMR. The data were compared statistically (Kruskal-Wallis/ Dunn, $\mathrm{p}<0.05$ ). Pure stevia, pure aspartame, xylitol and control were able to significantly reduce $92 \%$ of lactate production. Stevia finn, aspartame finn and sucrose showed similar production of lactic acid $(0.47 \pm 0.14,0.43 \pm 0.10,0.44 \pm$ $0.13 \mathrm{~g} / \mathrm{L} ; 0.69 \pm 0.19,0.65 \pm 0.11,0.67 \pm 0.24 \mathrm{~g} / \mathrm{L}$, for enamel and dentin, respectively, $p<0.0001$ ). With respect to total lactobacilli and $S$. mutans/S. sobrinus CFU, xylitol and control groups did not show growth on enamel, while CFU numbers were found in stevia finn, aspartame finn and sucrose groups for both tissues (5.69 \pm $0.44,5.69 \pm 0.82,5.75 \pm 0.60 \log _{10} \mathrm{CFU}$ total lactobacilli/mL; $7.57 \pm 0.37,7.61 \pm$ $0.64,7.49 \pm 0.41 \log _{10}$ CFU S. mutans $/ \mathrm{mL}$ for enamel; $0.00 \pm 3.98,5.30 \pm 5.30,5.30$ $\pm 0.15 \log _{10}$ CFU total lactobacilli/mL; $7.83 \pm 0.36,7.87 \pm 0.18 ; 7.78 \pm 0.31 \log _{10}$ CFU S. mutans $/ \mathrm{mL}$ for dentin, respectively). Enamel and dentin demineralization was significantly reduced for the groups xylitol, control, pure stevia and pure aspartame (around $85 \%$ and $83 \%$ reduction, respectively) compared to stevia finn, aspartame finn and sucrose, which in turn did not differ each other $(\Delta Z$ : $3084.7 \pm 834.3,3174.7$ $\pm 603.1,2913.7 \pm 646.7$ vol\%. $\mu \mathrm{m}$ for enamel e $3945.7 \pm 689.7,3626.8 \pm 617.3$, $3543.3 \pm 432.5$ vol\%. $\mu \mathrm{m}$ for dentin, respectively). Commercial sweeteners containing stevia and aspartame proved to be as cariogenic as sucrose in this experimental model, which is due to the other components, since the pure forms were not cariogenic. 


\section{Introduction}

Dental caries is a multifactorial oral disease highly impacting for the affected person especially when involves dentin. It is caused by a biofilm in disbiose, rich in acidogenic, aciduric and EPS (extracellular polysaccharide) producer microorganisms. These microorganisms are capable of metabolizing different types of sugar, mainly sucrose from the diet, forming acids that alter the biofilm $\mathrm{pH}$ and cause tooth demineralization (Keyes, 1960; Bowen, 2002; Marsh et al., 2011; Pitts et al., 2017; Ayoub et al., 2020).

Considering the relationship between dental caries and socioeconomic condition, it is obvious to infer that the consumption of common sugar (sucrose) is highly related to the disease, not only because it is low cost and easy access by the population, but also because bacteria can metabolize it easily. In addition, sucrose is the main substrate for the action of the glycosyltransferase responsible for the production of EPS, which is an important virulence factor of cariogenic bacteria (Paes-Leme et al., 2006; Ccahuana-Vásquez et al., 2007; Li et al., 2020). Accordingly, the World Health Organization (WHO) has recommended that the consumption of added sugar should not exceed more than $5 \%$ of the total energy consumed (around $10 \mathrm{~kg} / \mathrm{year}$ ), so that the number of DMFT is less than 3 in 12 years old children (Moyhinan, 2016; Moynihan \& Miller, 2020).

To replace common sugar, non-caloric sweeteners have been used by $28 \%$ of the population, in order to control obesity and diabetes mellitus (Jayalath et al., 2015; Azad et al., 2016; Manios et al., 2020). Sweeteners can be from natural (stevia) or synthetic origin (aspartame, acesulfame, sodium cyclamate, sucralose). In general, they present high sweetness, which is greater than sucrose itself. However, there is no evidence about the beneficial effects (control of obesity and diabetes) as well as about the side effects (cancer, headache and others) induced by the frequent consume of sweeteners (Lohner et al., 2017; Nichol et al., 2018; Santos et al., 2018). With respect to dental caries, few studies have shown that non-caloric sweeteners seem to be inert or at least not as cariogenic as sucrose (Giacaman et al., 2013; Giacaman, 2018).

Among the sweeteners, Stevia rebaudiana Bertoni, belonging to the Asteraceae family, is native from South America. Stevia leaves contain steviol glycosides, including stevioside, rebaudioside (A to F), steviolbioside and isosteviol, which are responsible for the sweet taste of the plant and have commercial value 
worldwide as a sugar substitute in food, beverages and medicines. In addition to its value as a sweetener, stevia and its glycosides have therapeutic effects against several diseases, such as cancer, diabetes mellitus, hypertension, inflammation, cystic fibrosis, obesity and tooth decay (Momtazi-Borojeni et al., 2017). Few studies have evaluated the effect of stevia on the development of cariogenic biofilm and/or of carious lesions, with inconclusive results regarding its anti-caries potential (Giacaman et al., 2013; Ma \& Blanksma, 2015; Ferrazzano et al., 2015; Kishta et al., 2016; Escobar et al., 2020). There is still a lack of evidence about its safety and benefits, which enable a safer recommendation of Stevia (Samuel et al., 2018).

Considering that obesity is associated with dental caries (Tinanoff \& Holt, 2017; Marro et al., 2021), due to the behavioural nature and dependency of sugar consumption for both diseases, and that the population have replaced common sugar by non-caloric sweeteners, it is necessary to know their anti-caries potential. Therefore, the aim of the work was to compare the effect of sweetener containing stevia (natural sweetener) to that with aspartame (synthetic sweetener), sucrose (common sugar) and xylitol (natural sweetener) on the development of dental caries in a microcosm biofilm model formed on enamel and dentin. The null hypothesis was that stevia has the same cariogenic potential as the other sweeteners and common sugar. 


\section{Material and Methods}

\section{Saliva collection}

This study was firstly approved by the local Ethical Committee (CEEA 12647819.5.0000.5417). After sign the informed consent, saliva was collected from 10 healthy donors, who have followed the inclusion criteria: 1) normal salivary flow (stimulated saliva flow $>1 \mathrm{~mL} / \mathrm{min}$ and non-stimulated saliva flow $>0.3 \mathrm{~mL} / \mathrm{min}$ ), 2) with previous history of caries, but no caries active (no active white spot and/or cavitated lesions), 3) without gingivitis/periodontitis (gum bleeding or tooth mobility) and, 4) without ingestion of antibiotics 3 months prior the experiment. On the day of collection, participants did not brush their teeth for $24 \mathrm{~h}$. Furthermore, they were not allowed to ingest food or drinks at least for $2 \mathrm{~h}$ before saliva collection. The saliva was collected under stimulation by chewing a rubber material for 10 min during the morning. After collection, saliva was diluted in glycerol $(70 \%$ saliva and $30 \%$ glycerol). Aliquots of $1 \mathrm{~mL}$ were stored at $-80^{\circ} \mathrm{C}$ (Pratten et al. 2003).

\section{Tooth sample preparation and treatment groups}

Two hundred and twenty-eight enamel and 228 root dentin samples (4 $\mathrm{mm} \times 4$ $\mathrm{mm}$ ) were prepared from bovine teeth, using a semi-precision cutting machine (Buehler, Enfield, USA). The samples fixed in acrylic discs were polished in a metallographic polishing machine (Arotec, Cotia, Brazil) using water-cooled siliconcarbide discs (320 and 600-grade papers ANSI grit; Buehler, Enfield, USA) to remove grooves (amount of removed tissue for enamel: $0.259 \pm 0.119 \mathrm{~mm}$ and dentin: $0.321 \pm 0.113 \mathrm{~mm}$ ). The roughness was measured using a contact profilometer and Mahr Surf XCR 20 software (Mahr, Göttingen, Germany) for the selection and randomly allocation of the samples in the experimental groups (enamel: $\mathrm{Ra}=0.130 \pm 0.032 \mu \mathrm{m}$; dentin: $\mathrm{Ra}=0.287 \pm 0.047 \mu \mathrm{m}$ ). Two thirds of the sample's surfaces were protected with nail polish to obtain control areas for the TMR analysis. The samples were sterilized using ethylene oxide [Gas exposure time (30\% $\mathrm{ETO} / 70 \% \mathrm{CO}_{2}$ ) for $4 \mathrm{~h}$ under a pressure of $\left.0.5 \pm 0.1 \mathrm{kgF} / \mathrm{cm}^{2}\right]$.

From the total samples, eighty-four samples were applied for lactic acid analysis, sixty for colony-forming unit (CFU) counting and eighty-four for transverse microradiography-TMR analysis. Enamel and dentin samples were randomly divided in the treatments according to the Ra means. All sugars/sweeteners were diluted in McBain saliva at $0.2 \%$ Their compositions are displayed in Table 1. 
Microcosm biofilm formation and treatments

The human saliva was defrosted and mixed with McBain artificial saliva (McBain, 2009) in a proportion of 1:50. The McBain saliva contained $2.5 \mathrm{~g} / \mathrm{L}$ mucin from porcine stomach (type II), $2.0 \mathrm{~g} / \mathrm{L}$ bacteriological peptone, $2.0 \mathrm{~g} / \mathrm{L}$ tryptone, 1.0 $\mathrm{g} / \mathrm{L}$ yeast extract, $0.35 \mathrm{~g} / \mathrm{L} \mathrm{NaCl}, 0.2 \mathrm{~g} / \mathrm{L} \mathrm{KCl}, 0.2 \mathrm{~g} / \mathrm{L} \mathrm{CaCl}_{2}, 0.1 \mathrm{~g} / \mathrm{L}$ cysteine hydrochloride, $0.001 \mathrm{~g} / \mathrm{L}$ hemin, $0.0002 \mathrm{~g} / \mathrm{L}$ vitamin $\mathrm{K} 1$, at $\mathrm{pH}$ 7.0. All reagents were from Sigma-Aldrich. This solution was added to each well containing an enamel or dentin sample ( $\mathrm{v}=1.5 \mathrm{~mL} /$ well) in 24-well plate, which was incubated at $5 \% \mathrm{CO}_{2}$ and $37^{\circ} \mathrm{C}$. After $8 \mathrm{~h}$, the medium was removed, the enamel/dentin samples were washed using phosphate-buffered saline (PBS, $5 \mathrm{~s}$ ) and fresh McBain saliva was added into the wells $\left(\mathrm{v}=1.5 \mathrm{~mL} /\right.$ well). The plates were incubated at $5 \% \mathrm{CO}_{2}$ and $37^{\circ} \mathrm{C}$ for further $16 \mathrm{~h}$, completing the first day.

From the $2^{\text {nd }}$ to the $5^{\text {th }}$ day, McBain saliva supplemented with $0.2 \%$ sweeteners/sugar was added to each well containing an enamel or dentin sample. The plate was incubated at the same conditions described above (Zhang et al. 2013). Figure 1 summarizes the experimental protocol.

\section{Colony-forming unit (CFU) counting}

For CFU counting, $100 \mu \mathrm{L}$ of the bacterial suspension from microcosm biofilm were then diluted to $10^{-4}$ and spread on petri dishes (25 $\mu \mathrm{L} /$ dish) containing four different types of agar: 1) Brain Heart Infusion agar (BHI, Difco, Detroit, USA) for total microorganisms and 2) Mitis Salivarius Agar (MSA, Neogen, Indaiatuba, Brazil) containing $20 \%$ sucrose and $1 \%$ potassium tellurite for total streptococci (Lima et al. 
2009); 3) SB-20M (Saravia et al. 2011) containing $15 \mathrm{~g}$ bacto-casitone (Difco, Detroit, USA), $5 \mathrm{~g}$ yeast extract (Kasvi, Curitiba, Brazil), $0.2 \mathrm{~g}$ L-Cysteine hydro-chloride (Sigma, Steinheim, Germany), $0.1 \mathrm{~g}$ sodium sulfite (Sigma, Steinheim, Germany), $20.0 \mathrm{~g}$ sodium acetate (Synth, Diadema, Brazil), $200.0 \mathrm{~g}$ coarse granular cane sugar, $15.0 \mathrm{~g}$ agar (Kasvi, Curitiba, Brazil), and $1 \mathrm{~L}$ distilled water. After autoclaving for 20 $\min$ at $120^{\circ} \mathrm{C}, 0.2 \mathrm{U} / \mathrm{mL}$ bacitracin (Sigma, Steinheim, Germany) was added for determination of mutans streptococci (S. mutans and S. sobrinus); and 4) Rogosa (Kasvi, Curitiba, Brazil) supplemented with $0.13 \%$ glacial acetic acid to assess the number of lactobacilli (Lima et al. 2009).

The plates were then incubated at $5 \% \mathrm{CO}_{2}$ and $37^{\circ} \mathrm{C}$. After $48 \mathrm{~h}$, the $\mathrm{CFU}$ numbers were counted and transformed in $\log _{10} \mathrm{CFU} / \mathrm{mL}$ (Cheng et al. 2012).

\section{Transverse microradiography (TMR)}

After cleaning, all enamel and dentin samples were transversally sectioned and polished to obtain slices with 80-100 $\mu \mathrm{m}$ (enamel) and 100-120 $\mu \mathrm{m}$ (dentin) of thickness. The enamel and dentin slices were fixed in a sample-holder together with an aluminium calibration step wedge with 14 steps. A microradiograph was taken using an x-ray generator (Softex, Tokyo, Japan) on the glass plate at $20 \mathrm{kV}$ and 20 $\mathrm{mA}$ (at a distance of $42 \mathrm{~cm}$ ) for $13 \mathrm{~min}$. The glass plates were developed for $7 \mathrm{~min}$, rinsed in deionized water, fixed for $7 \mathrm{~min}$ in a dark environment, and then rinsed in running water for $10 \mathrm{~min}$ and air-dried (all procedures were done at $20^{\circ} \mathrm{C}$ ). The developed plate was analysed using a transmitted light microscope fitted with a 20x objective (Zeiss, Oberkochen, Germany), a CCD camera (Canon, Tokyo, Japan) and a computer. Two images per sample were taken using data-acquisition (version 2012) and interpreted using calculation (version 2006) softwares from Inspektor Research System bv (Amsterdam, The Netherlands). The mineral content was calculated based on the work of Angmar et al. (1963), assuming $87 \mathrm{vol} \%$ of mineral content for sound enamel and $50 \%$ of mineral content for sound dentin. The lesion depth $(\mathrm{LD}, \mu \mathrm{m})$, the integrated mineral loss $(\Delta \mathrm{Z}, \mathrm{vol} \% . \mu \mathrm{m})$ and the average mineral loss over the lesion depth ( $\mathrm{R}$, vol\%) were calculated.

\section{Statistical Analysis}


All experiments were performed in biological quadruplicate $\left(\mathrm{n}_{\text {final }}=12\right)$. Data were statistically analysed using software Graph Pad Instat for Windows (GraphPad Software, San Diego, USA).

The normality (Kolmogorov-Smirnov's test) and homogeneity (Bartlett's test) of the data were tested. Since the data did not pass the homogeneity test, all data were compared using Kruskal-Wallis followed by Dunn test. The level of significance was set at $5 \%$.

\section{Results}

Enamel

Pure stevia, pure aspartame, xylitol and control presented similar low lactate production compared to the commercial versions of the sweeteners and sucrose. On the other hand, stevia finn, aspartame finn and sucrose presented the highest lactic acid production, with no difference between them (Figure 2).

Sucrose induced the highest growth of total microorganism compared to all groups, except to stevia finn that did not differ from all groups. No growth of total lactobacilli, total streptococci and S. mutans was seen for xylitol and control groups, while stevia finn, aspartame finn and sucrose presented similar microorganisms' growth (Table 2).

The integrated mineral loss and lesion depth were reduced in enamel samples exposed to pure stevia, pure aspartame, xylitol and control $(\approx 85 \%$ reduction) compared to sucrose, which in turn had a similar cariogenic effect to the tested commercial sweeteners (aspartame finn and stevia finn) (Table 3 and Figure 3). With respect to mineral loss mean, only enamel samples belonging to xylitol and control groups presented reduced values compared to sucrose.

\section{Dentin}

Pure stevia, pure aspartame, xylitol and control presented similar low lactate production compared to the commercial versions of the sweeteners and sucrose. On the other hand, stevia finn, aspartame finn and sucrose presented the highest lactic acid production, with no difference between them (Figure 4).

Stevia finn, xylitol and control reduced significantly the number of total microorganism and total lactobacilli in the biofilm. Stevia finn also reduced CFU for 
total streptococci significantly, but only xylitol and control had antimicrobial effect on S. mutans (around $1.8 \log _{10}$ reduction compared to the other groups) (Table 4).

The integrated mineral loss, mineral loss mean and lesion depth were reduced in dentin samples exposed to pure stevia, pure aspartame, xylitol and control (> 83\% reduction) compared to sucrose, which in turn had a similar cariogenic effect to the tested commercial sweeteners (aspartame finn and stevia finn) (Table 5 and Figure 5).

\section{Discussion}

The natural sweetener stevia is considered one of the best substitutes for sucrose, as it has low calories and no report about adverse effects (Contreras, 2013; Salvador-Reyes et al., 2014). The plant, from which this sweetener is obtained, is rich in carbohydrates, proteins, crude fibber, minerals $\left(\mathrm{K}^{+}, \mathrm{Ca}^{2+}, \mathrm{Na}^{+}, \mathrm{Mg}^{2+}, \mathrm{Cu}^{2+}\right.$, $\left.\mathrm{Mn}^{2+}, \mathrm{Fe}^{2+}, \mathrm{Zn}^{2+}\right)$ and essential amino acids. It has a high percentage of steviol (stevioside, steviolbioside, rebaudioside AF and dulcoside) (Escobar et al., 2020), which in turn has been responsible for its antimicrobial effect (Ferrazzano et al., 2015). However, its role in preventing caries and promoting oral health is not fully understood.

Stevioside offers several advantages over other non-caloric substitutes since it is heat-stable, resistant to acid hydrolysis and non-fermentable (Giongo et al., 2014). The data suggest that steviol glycosides are not cariogenic and may have beneficial effects in preventing dental caries (Samuel et al., 2018).

Our work has shown that a commercial sweetener containing stevia is as cariogenic as sucrose, although some antimicrobial effect has been seen in the biofilm formed on dentin. Escobar et al. (2020) demonstrated that, even with the presence of stevia, S. mutans managed to metabolize sucrose and to produce acids, being stevia ineffective in reducing microbial viability.

Part of stevia's cariogenic effect, seen in the present work, can be justified by the presence of lactose with an estimated concentration of $94 \%$ This sugar may have been metabolized by the biofilm bacteria and responsible for the dental demineralization. When there are two sources of energy supply (for example, stevia and lactose), bacteria can adapt to the conditions of the environment and metabolize one of the two sources of energy from which it obtains more energy, as discussed by. Therefore, we decided to test the pure form of stevia, whose data of lactic acid assay 
and TMR confirmed that the sweetener is in fact not cariogenic and that the results found for the commercial product was due to the presence of lactose. We did not perform CFU counting in case of pure stevia, since the results of the other methods were enough to show their non-cariogenic potential. Based on it, the null hypothesis was rejected.

A similar result was seen for the commercial sweetener containing aspartame (and also lactose) in our work, which was as cariogenic as stevia and sucrose. Aspartame is a dipeptide ester (aspartic acid is attached to the $\mathrm{N}$-terminal portion of phenylalanine), presented as a white crystalline powder with a refreshing aroma and characteristic of a sweet flavour. In an aqueous solution, aspartame is about 160 times sweeter than sucrose (Matsukubo \& Takazoe, 2006).

According to Giacaman et al. (2013), using a monospecie biofilm (S. mutans), aspartame reduced the biofilm $\mathrm{pH}$ around 5.4 after $80 \mathrm{~h}$, value higher than that induced by sucrose, but very close to the critical $\mathrm{pH}$ for apatite. In the cited study, the biofilm exposed to stevia during this period had a $\mathrm{pH}$ of around 6.0, value closed with what was found for Giongo et al. (2014) using 7\% stevioside and 93\% lactose. Regarding the biofilm biomass, all the sugars and sweeteners mentioned showed a high value compared to the control group $(\mathrm{NaCl})$. All sugars and sweeteners showed cariogenic potential, but sucrose was the most cariogenic one. After 5 days of biofilm cultivation, enamel demineralization induced by fructose $(30 \%$ loss of microhardness), aspartame (approximately 23\%) and stevia (approximately 18\%) was significantly lower when compared to the sucrose (approximately 43\%). In our study, the cariogenic potential of the commercial aspartame was due to the presence of lactose (94\%), which was proved by the TMR images of pure aspartame. Differently what was shown above, we found similarity between the commercial sweeteners and sucrose, which may be due to the experimental model (continuous exposure of microcosm biofilm to sweeteners/sugar for 5 days) and the response variable (TMR).

Artificial sweeteners are usually hundreds of times sweeter than sucrose. In our study, we tested all groups at the same concentration, but in the real situation the amount of sweetener applied is usually much lower than sucrose. Products containing sweeteners, for this reason, cannot be sold in their pure form. For example, a tablet of a commercial product advertised as sucralose usually contains only about $10 \%$ sucralose, with higher proportions of other carbohydrates, usually 
305 lactose, starch or starch hydrolysates (Giacaman et al., 2013). Although lactose is 306 considered one of the least cariogenic common sugars, evidence points out that 307 repeated exposures to this carbohydrate can lead microorganisms (S. mutans) to adapt and to produce acids from lactose, more quickly over time (Hamilton \& Letbag, 1979; Birkhed et al., 1993; Zeng et al., 2010).

As expected, xylitol (anti-cariogenic) and control (no supplementation) groups significantly reduced the number of microorganisms in biofilm. Xylitol (sugar alcohol of $5 \mathrm{C}$ ) is not easily metabolized by cariogenic microorganisms. The decrease in the $\mathrm{pH}$ of the biofilm caused by this sugar is not enough to cause enamel demineralization (Marghalani et al., 2017). Streptococcus mutans, gram-positive bacteria identified as being primarily responsible for the caries process, do not metabolize xylitol for obtaining energy. Xylitol is transported into cells by the induced action of a fructose transporter, however, it causes a futile cycle because it is not going through to glycolytic reactions or, when accumulated, induces cell damage (Ly et al., 2008; Masoud et al., 2015; Riley et al., 2015). Xylitol is also known to improve remineralization of artificial caries lesions in vitro and in situ (Cardoso et al., 2014; Cardoso et al., 2016).

Future studies can be designed in order to understand the cariogenic potential of different pure and commercial sweeteners using models closer to the in vivo condition such as in situ models. With more scientific evidence, the population shall be advised about the different cariogenic potential among the sweeteners brand names.

In conclusion, commercial sweeteners containing stevia and aspartame (Finn trademark) demonstrated to be as cariogenic as sucrose in this experimental model, due to the presence of other components, since the pure forms of the sweeteners are not cariogenic.

\section{Acknowledgments}

We thank FAPESP for the concession of a scholarship to the first author (Proc. 2019/02018-0). This publication is a thesis submitted by the first author to Bauru School of Dentistry, University of São Paulo, in fulfilment of the requirements for a MS degree in Oral Biology. 


\section{Statement of Ethics}

This study was approved by the local Ethics Committee (Number: 12647819.5.0000.5417) and Ethics committee on animal research (CEUA, Number: 004/2019).

\section{Disclosure Statement}

The authors declare no potential conflict of interest.

\section{Funding Sources}

This work was supported by the São Paulo Research Foundation (FAPESP 2019/02018-0).

\section{Author Contributions}

Nascimento CA, Kim RR and Ferrari CR performed the experiments. Nascimento CA, Braga AS, Souza BM and Magalhães $A C$ designed the project. Magalhães AC supervised all the experiments. Nascimento CA and Magalhães AC analyzed the data and wrote the manuscript. All authors revised and approved the paper.

\section{References}

Angmar B, Carlström D, Glas JE. Studies on the ultrastructure of dental enamel. IV The mineralization of normal human enamel. J Ultrastruct Res. 1963;8:12-33.

Ayoub HM, Gregory RL, Tang Q, Lippert F. Influence of salivary conditioning and sucrose concentration on biofilm-mediated enamel demineralization. J Appl Oral Sci. 2020;28:e20190501.

Azad MB, Sharma AK, de Souza RJ, Dolinsky VW, Becker AB, Mandhane PJ, et al. Canadian healthy infant longitudinal development study Investigators. Association Between Artificially Sweetened Beverage Consumption During Pregnancy and Infant Body Mass Index. JAMA Pediatr. 2016;1;170(7):662-670.

Birkhed D, Imfeld T, Edwardsson S. pH changes in human dental plaque from lactose and milk before and after adaptation. Caries Res. 1993;27:43-50.

Bowen $\mathrm{WH}$. Do we need to be concerned about dental caries in the coming millennium? Crit Oral Biol Med. 2002;13:126-131. 
372 Cardoso CA, de Castilho AR, Salomao PM, Costa EN, Magalhaes AC, Buzalaf MA. 373 Effect of xylitol varnishes on remineralization of artificial enamel caries lesions in 374 vitro. J Dent. 2014;42:1495-1501.

375 Cardoso CA, Cassiano LP, Costa EN, Souza-E-Silva CM, Magalhães AC, Grizzo LT 376 et al. Effect of xylitol varnishes on remineralization of artificial enamel caries lesions 377 in situ. J Dent. 2016;50:74-78.

378 Ccahuana-Vásquez RA, Tabchoury CP, Tenuta LM, Del Bel Cury AA, Vale GC, Cury 379 JA. Effect of frequency of sucrose exposure on dental biofilm composition and 380 enamel demineralization in the presence of fluoride. Caries Res. 2007;41(1):9-15.

381 Cheng L, Weir MD, Zhang K, Wu EJ, Xu SM, Zhou X, et al. Dental plaque microcosm 382 biofilm behavior on calcium phosphate nanocomposite with quaternary ammonium. 383 Dent Mater. 2012;28:853-862.

384 Contreras S. Anticariogenic properties and effects on periodontal structures of Stevia 385 rebaudiana Bertoni. Narrative review. J Oral Res. 2013;2(3):158-166.

386 Escobar E, Piedrahita M, Gregory RL. Growth and viability of Streptococcus mutans 387 in sucrose with different concentrations of Stevia rebaudiana Bertoni. Clin Oral 388 Investig. 2020;24(9):3237-3242.

389 Ferrazzano GF, Cantile T, Alcidi B, Coda M, Ingenito A, Zarrelli A et al. Is Stevia 390 rebaudiana Bertoni a Non Cariogenic Sweetener? A Review. Molecules. $3912015 ; 21(1):$ :E38.

392 Giacaman RA, Campos P, Muñoz-Sandoval C, Castro RJ. Cariogenic potential of 393 commercial sweeteners in an experimental biofilm caries model on enamel. Arch Oral 394 Biol. 2013;58(9):1116-1122.

395 Giacaman RA. Sugars and beyond. The role of sugars and the other nutrients and 396 their potential impact on caries. Oral Dis. 2018;24(7):1185-1197.

397 Giongo FC, Mua B, Parolo CC, Carlén A, Maltz M. Effects of lactose-containing 398 stevioside sweeteners on dental biofilm acidogenicity. Braz Oral Res. 2014;28:0026.

399 Hamilton IR, Lebtag H. Lactose metabolism by Streptococcus mutans: Evidence for 400 induction of the tagatose 6-phosphate pathway. J Bacteriol. 1979;140(3):1102-1104. 401 Jayalath VH, de Souza RJ, Ha V, Mirrahimi A, Blanco-Mejia S, Di Buono M, et al. 402 Sugar-sweetened beverage consumption and incident hypertension: a systematic 403 review and meta-analysis of prospective cohorts. Am J Clin Nutr. 2015;102(4):914404921. 
405

406

407

408

409

410

411

412

413

414

415

416

417

418

419

420

421

422

423

424

425

426

427

428

429

430

431

432

433

434

435

436

437

Keyes $\mathrm{PH}$. The infectious and transmissible nature of experimental dental caries. Findings and implications. Arch Oral Biol. 1960;1:304-320.

Kishta OA, Derani M, Neiva GF, Boynton JR, Kim YE, Fontana M. The antimicrobial potential of stevia in an in vitro microbial caries model. Am J Dent. 2016;29(2):87-92.

Li J, Wu T, Peng W, Zhu Y. Effects of resveratrol on cariogenic virulence properties of Streptococcus mutans. BMC Microbiol. 2020;20(1):99.

Lima JP, Sampaio de Melo MA, Borges FM, Teixeira AH, Steiner-Oliveira C, Nobre Dos Santos $M$, et al. Evaluation of the antimicrobial effect of photodynamic antimicrobial therapy in an in situ model of dentine caries. Eur $\mathrm{J}$ Oral Sci. 2009;117:568-574.

Lohner S, Toews I, Meerpohl JJ. Health outcomes of non-nutritive sweeteners: analysis of the research landscape. Nutr J. 2017;16(1):55.

Ly KA, Milgrom P, Rothen M. The potential of dental-protective chewing gum in oral health interventions. JADA. 2008;139(5):553-563.

Ma MS, Blanksma NG. Stevia in the fight against dental caries. Ned Tijdschr Tandheelkd. 2015;122(1):51-55.

Manios Y, Lambrinou CP, Mavrogianni C, Cardon G, Lindström J, lotova V, et al. Lifestyle Changes Observed among Adults Participating in a Family- and CommunityBased Intervention for Diabetes Prevention in Europe: The 1st Year Results of the Feel4Diabetes-Study. Nutrients. 2020;30;12(7):E1949.

Marghalani AA, Guinto $E$, Phan M, Dhar V, Tinanoff N. Effectiveness of Xylitol in Reducing Dental Caries in Children. Pediatr Dent. 2017;39(2):103-110.

Marro F, De Smedt S, Rajasekharan S, Martens L, Bottenberg P, Jacquet W. Associations between obesity, dental caries, erosive tooth wear and periodontal disease in adolescents: a case-control study. Eur Arch Paediatr Dent. 2021; 22(1):99-108.

Marsh PD, Moter A, Devine DA. Dental plaque biofilms: communities, conflict and control. Periodontol 2000. 2011;55:16-35.

Masoud MI, Allarakia R, Alamoudi NM, Nalliah R, Allareddy V. Long-term clinical and bacterial effects of xylitol on patients with fixed orthodontic appliances. Prog Orthod. 2015;16(35):18-20.

Matsukubo T, Takazoe I. Sucrose substitutes and their role in caries prevention. Int Dent J. 2006;56(3):119-130.

McBain AJ. In vitro biofilm models: an overview. Adv Appl Microbiol. 2009;69:99-132. 
439 Momtazi-Borojeni AA, Esmaeili SA, Abdollahi E, Sahebkar A. A Review on the 440 pharmacology and toxicology of steviolglycosides extracted from Stevia rebaudiana. 441 Curr Pharm Des. 2017;23(11):1616-1622.

442 Moynihan P, Miller C. Beyond the Chair: Public Health and Governmental Measures 443 to Tackle Sugar. J Dent Res. 2020;99(8):871-876.

444 Moynihan P. Sugars and dental caries: evidence for setting a recommended 445 threshold for intake. Adv Nutr. 2016;7(1):149-156.

446 Nichol AD, Holle MJ, An R. Glycemic impact of non-nutritive sweeteners: a 447 systematic review and meta-analysis of randomized controlled trials. Eur J Clin Nutr. $448 \quad 2018 ; 72: 796-804$.

449 Paes Leme AF, Koo H, Bellato CM, Bedi G, Cury JA. The role of sucrose in 450 cariogenic dental biofilm formation-new insight. J Dent Res. 2006;85(10):878-887.

451 Pitts NB, Zero DT, Marsh PD, Ekstrand K, Weintraub JA, Ramos-Gomez F, et al. 452 Dental caries. Nat Rev Dis Primers. 2017;25(3):17030.

453 Pratten J, Wilson M, Spratt DA. Characterization of in vitro oral bacterial biofilms by 454 traditional and molecular methods. Oral Microbiol Immunol. 2003;18:45-49.

455 Riley P, Moore D, Ahmed F, Sharif MO, Worthington HV. Xylitol containing products 456 for preventing dental caries in children and adults. Cochrane Database Syst Rev. 457 2015;26(3):CD010743.

458 Salvador-Reyes R, Sotelo-Herrera M, Paucar-Menacho L. Study of Stevia (Stevia 459 rebaudiana Bertoni) as a natural sweetener and its use in benefit of the health. 460 Scientia Agropecuaria. 2014;5(3):157-163.

461 Samuel P, Ayoob KT, Magnuson BA, Wölwer-Rieck U, Jeppesen PB, Rogers PJ, et 462 al. Stevia Leaf to Stevia Sweetener: Exploring Its Science, Benefits, and Future 463 Potential. J Nutr. 2018;148(7):1186S-1205S.

464 Santos PS, Caria CRP, Gotardo EMF, Ribeiro ML, Pedrazzoli J, Gambero A. Artificial 465 sweetener saccharin disrupts intestinal epithelial cells' barrier function in vitro. Food 466 Funct. 2018;9(7):3815-3822.

467 Saravia ME, Nelson-Filho P, Ito IY, da Silva LA, da Silva RA, Emilson CG. 468 Morphological differentiation between S. mutans and S. sobrinus on modified SB-20 469 culture medium. Microbiol Res. 2011;166:63-67.

470 Tinanoff N, Holt K. Children's Sugar Consumption: Obesity and Dental Caries. 471 Pediatr Dent. 2017;39(1):12-13. 
472 Zeng L, Das S, Burne RA. Utilization of lactose and galactose by Streptococcus 473 mutans: transport, toxicity, and carbon catabolite repression. J Bacteriol. 474 2010;192(9):2434-2444.

475 Zhang K, Cheng L, Imazato S, Antonucci JM, Lin NJ, Lin-Gibson S, et al. Effects of 476 dual antibacterial agents MDPB and nano-silver in primer on microcosm biofilm, 477 cytotoxicity and dentin e bond properties. J Dent. 2013;41:464-474. 
Table 1. Composition of sweeteners

\begin{tabular}{|c|c|c|}
\hline Product's name & Brand / City-Country & Composition \\
\hline $\begin{array}{l}\text { Finn } 100 \% \\
\text { Stevia }{ }^{\circledR}\end{array}$ & $\begin{array}{c}\text { Hypera Pharma/São Paulo- } \\
\text { Brazil }\end{array}$ & $\begin{array}{l}\text { Lactose, steviol glycoside sweetener and } \\
\text { silicon dioxide anti-humectant. }\end{array}$ \\
\hline Pure Stevia & Merck & $\begin{array}{c}\text { Stevioside; Rebaudiosides A, B, C and D; } \\
\text { Dulcoside A; Rubusoside; Steviolbioside; } \\
\text { Stevioside. }\end{array}$ \\
\hline Finnaspartame ${ }^{\circledR}$ & $\begin{array}{c}\text { Hypera Pharma/São Paulo- } \\
\text { Brazil }\end{array}$ & $\begin{array}{l}\text { Lactose, aspartame sweetener and } \\
\text { anti-wetting silicon dioxide. }\end{array}$ \\
\hline Pure Aspartame & Merck & Aspartame \\
\hline Sucrose & Merck & Sucrose \\
\hline $\begin{array}{c}\text { Xilitol } \\
\text { (Finesweet)® }\end{array}$ & $\begin{array}{c}\text { Airon Ind. E Com. de Prod. } \\
\text { Alimt. LTDA/ Ribeirão Preto- } \\
\text { Brazil }\end{array}$ & Xylitol \\
\hline
\end{tabular}

* The pure sweeteners were tested in lactate assay and TMR analysis. 
Table 2. CFU counting $\log _{10} / \mathrm{mL}$ [median (interquartile range)] for Total $\mathrm{M} \varnothing$, total lactobacilli, total streptococci and S. mutans/S. sobrinus in the microcosm biofilm formed on the enamel and exposed to different sugars / sweeteners.

\begin{tabular}{ccccc}
\hline Groups & Total Mø & $\begin{array}{c}\text { total } \\
\text { lactobacilli }\end{array}$ & $\begin{array}{c}\text { total } \\
\text { streptococci }\end{array}$ & $\begin{array}{c}\text { S. mutans/ } \\
\text { S. sobrinus }\end{array}$ \\
\hline Stevia Finn & $6.54(0.41)^{\mathrm{AB}}$ & $5.69(0.44)^{\mathrm{A}}$ & $7.27(0.53)^{\mathrm{A}}$ & $7.57(0.37)^{\mathrm{A}}$ \\
\hline Aspartame Finn & $6.84(1.31)^{\mathrm{A}}$ & $5.69(0.82)^{\mathrm{A}}$ & $7.42(0.32)^{\mathrm{A}}$ & $7.61(0.64)^{\mathrm{A}}$ \\
\hline Xylitol & $5.89(0.45)^{\mathrm{A}}$ & $5.30(0.00)^{\star *}$ & $5.60(0.23)^{\star *}$ & $5.60(0.63)^{\star *}$ \\
\hline Sucrose & $7.15(0.36)^{\mathrm{B}}$ & $5.75(0.60)^{\mathrm{A}}$ & $7.09(0.61)^{\mathrm{A}}$ & $7.49(0.41)^{\mathrm{A}}$ \\
\hline $\begin{array}{c}\text { Control (no } \\
\text { supplementation) }\end{array}$ & $6.16(0.89)^{\mathrm{A}}$ & $6.26(0.66)^{\star *}$ & $5.30(0.23)^{\star *}$ & $5.78(1.30)^{\star *}$ \\
\hline
\end{tabular}

${ }^{*} \overline{\text { Groups excluded from statistical analysis because they did not show considerable colonies }}$ growth. With respect to total lactobacilli, total streptococci and $S$. mutans, Xylitol group presented $80 \%, 53.4 \%$ and $46.7 \%$ of samples without growth, respectively, while the Control group presented $86.7 \%, 66.7 \%$ and $60 \%$, respectively.

Kruskal-Wallis/Dunn test $(\mathrm{p}<0.0001, \mathrm{p}=0.809, \mathrm{p}=0.169$ and $\mathrm{p}=0.9579$ for total Microorganisms, total lactobacilli, total streptococci and S. mutans /S. sobrinus, respectively). $n=12$. Different letters represent groups with statistical differences. 
Table 3. TMR analysis of the enamel samples

\begin{tabular}{cccc}
\hline Groups & $\begin{array}{c}\Delta \mathbf{Z} \\
(\text { vol\%. } \mu \mathrm{m})\end{array}$ & $\begin{array}{c}\text { LD } \\
(\mu \mathrm{m})\end{array}$ & $\begin{array}{c}\mathbf{R} \\
(\text { vol\% })\end{array}$ \\
\hline Stevia Finn & $3084.67(834.26)^{\mathrm{A}}$ & $89.78(27.61)^{\mathrm{A}}$ & $31.59(5.77)^{\mathrm{A}}$ \\
\hline Pure Stevia & $668.46(302.45)^{\mathrm{B}}$ & $25.39(15.93)^{\mathrm{B}}$ & $27.82(10.17)^{\mathrm{ABC}}$ \\
\hline Aspartame Finn & $3174.67(603.10)^{\mathrm{A}}$ & $86.87(25.56)^{\mathrm{A}}$ & $33.95(5.36)^{\mathrm{A}}$ \\
\hline Pure Aspartame & $410.83(209.93)^{\mathrm{B}}$ & $23.19(18.08)^{\mathrm{B}}$ & $22.62(8.96)^{\mathrm{BC}}$ \\
\hline Sucrose & $2913.67(646.69)^{\mathrm{A}}$ & $78.05(19.47)^{\mathrm{A}}$ & $31.14(4.06)^{\mathrm{AB}}$ \\
\hline Xylitol & $422.00(196.48)^{\mathrm{B}}$ & $21.23(7.55)^{\mathrm{B}}$ & $19.91(5.19)^{\mathrm{C}}$ \\
\hline $\begin{array}{c}\text { Control (no } \\
\text { supplementation) }\end{array}$ & $326.00(173.24)^{\mathrm{B}}$ & $15.25(7.36)^{\mathrm{B}}$ & $20.16(3.87)^{\mathrm{C}}$
\end{tabular}

Kruskal-Wallis / Dunn [median (interquartile range), $\Delta Z-p<0.0001 ; P-p<0.0001 ; R-p<$ 0.0001]. $n=12$. Different letters in the same column represent groups with significant differences. 
Table 4. CFU counting $\log _{10} / \mathrm{mL}$ [median (interquartile range)] for Total $\mathrm{M} \varnothing$, total lactobacilli, total streptococci and S. mutans/S. sobrinus in the microcosm biofilm formed on the dentin and exposed to different sugars /sweeteners

\begin{tabular}{|c|c|c|c|c|}
\hline Grupos & Mø Totais & $\begin{array}{c}\text { total } \\
\text { lactobacilli }\end{array}$ & $\begin{array}{c}\text { total } \\
\text { streptococci }\end{array}$ & $\begin{array}{l}\text { S. mutans/ } \\
\text { S. sobrinus }\end{array}$ \\
\hline Stevia Finn & $6.42(0.44)^{A}$ & $0.00(3.98)^{A B}$ & $5.80(0.40)^{\mathrm{A}}$ & $7.83(0.36)^{A}$ \\
\hline Aspartame Finn & $7.09(0.67)^{\mathrm{BC}}$ & $5.30(5.30)^{\mathrm{BC}}$ & $6.31(0.45)^{A B}$ & $7.87(0.18)^{A}$ \\
\hline Xylitol & $6.72(0.27)^{A B}$ & $0.00(0.00)^{A}$ & $6.60(0.34)^{B}$ & $6.15(0.37)^{\mathrm{B}}$ \\
\hline Sucrose & $7.24(0.38)^{C}$ & $5.30(0.15)^{C}$ & $6.45(0.25)^{B}$ & $7.78(0.31)^{A}$ \\
\hline $\begin{array}{c}\text { Control (no } \\
\text { supplementation) }\end{array}$ & $6.82(0.36)^{\mathrm{AB}}$ & $0.00(0.00)^{* *}$ & $6.55(0.54)^{\mathrm{B}}$ & $5.78(1.21)^{B}$ \\
\hline
\end{tabular}


Table 5. TMR analysis of the dentin samples

\begin{tabular}{cccc}
\hline Groups & $\begin{array}{c}\Delta \mathbf{Z} \\
(\text { vol\%. } \mu \mathrm{m})\end{array}$ & $\begin{array}{c}\text { LD } \\
(\mu \mathrm{m})\end{array}$ & $\begin{array}{c}\mathbf{R} \\
(\mathrm{vol} \%)\end{array}$ \\
\hline Stevia Finn & $3945.67(689.69)^{\mathrm{A}}$ & $115.23(18.25)^{\mathrm{A}}$ & $30.06(3.74)^{\mathrm{A}}$ \\
\hline Pure Stevia & $557.14(249.35)^{\mathrm{B}}$ & $54.64(36.34)^{\mathrm{B}}$ & $11.65(7.51)^{\mathrm{B}}$ \\
\hline Aspartame Finn & $3626.79(617.26)^{\mathrm{A}}$ & $120.87(13.68)^{\mathrm{A}}$ & $30.95(4.78)^{\mathrm{A}}$ \\
\hline Pure Aspartame & $520.71(181.89)^{\mathrm{B}}$ & $42.24(21.81)^{\mathrm{B}}$ & $14.26(5.57)^{\mathrm{B}}$ \\
\hline Sucrose & $3543.33(432,50)^{\mathrm{A}}$ & $117.83(9.33)^{\mathrm{A}}$ & $31.42(3.12)^{\mathrm{A}}$ \\
\hline Xylitol & $720.00(156.32)^{\mathrm{B}}$ & $41.33(12.83)^{\mathrm{B}}$ & $14.00(2.89)^{\mathrm{B}}$ \\
\hline $\begin{array}{c}\text { Control (no } \\
\text { supplementation) }\end{array}$ & $673.57(176.61)^{\mathrm{B}}$ & $47.49(15.39)^{\mathrm{B}}$ & $14.41(2.66)^{\mathrm{B}}$
\end{tabular}

Kruskal-Wallis / Dunn [median (interquartile range), $\Delta Z-p<0.0001 ; P-p<0.0001 ; R-p<$ $0.0001]$. $n=12$. Different letters in the same column represent groups with significant differences. 


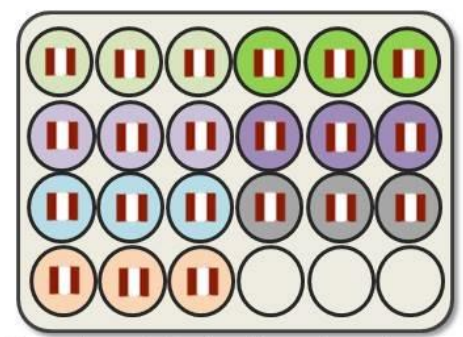

Sample $+1.5 \mathrm{~mL}$ of inoculum (human saliva + McBain saliva)

$8 \mathrm{~h}$ incubation $\left(37^{\circ} \mathrm{C}, 5 \% \mathrm{CO}_{2}\right)$

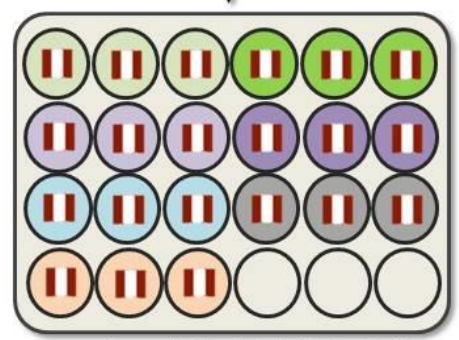

Sample + $1.5 \mathrm{~mL}$ McBain Saliva

$$
16 \mathrm{~h} \text { incubation }
$$
$\left(37^{\circ} \mathrm{C}, 5 \% \mathrm{CO}_{2}\right)$

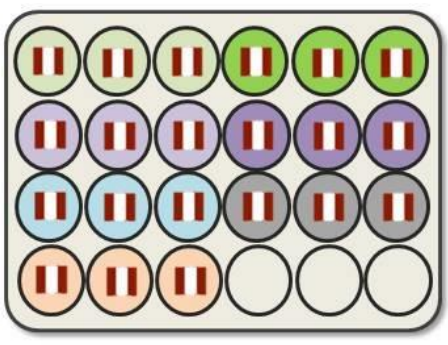

Upon completing $24 \mathrm{~h}$ of biofilm cultivation, McBain Saliva was supplemented with $0,2 \%$ sugar/sweeteners for $24 \mathrm{~h}$.

$24 \mathrm{~h}$ incubation $\left(37^{\circ} \mathrm{C}, 5 \% \mathrm{CO}_{2}\right)$

From the $2^{\text {nd }}$ to the $5^{\text {th }}$ day of

Exchanges were made once a day biofilm cultivation

1 - Lactic acid production

2 - Colony-forming unit (CFU) counting

3 - Transverse microradiography (TMR)

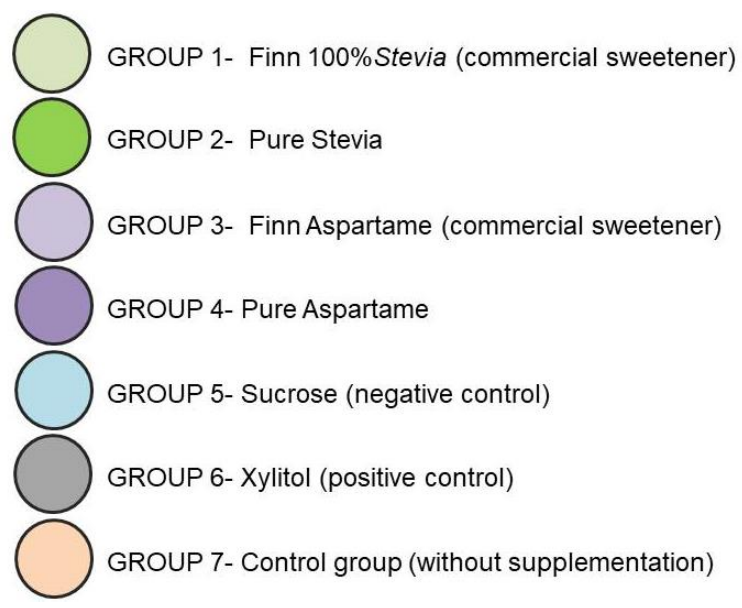

Figure 1. Representative images of the experimental protocol. 


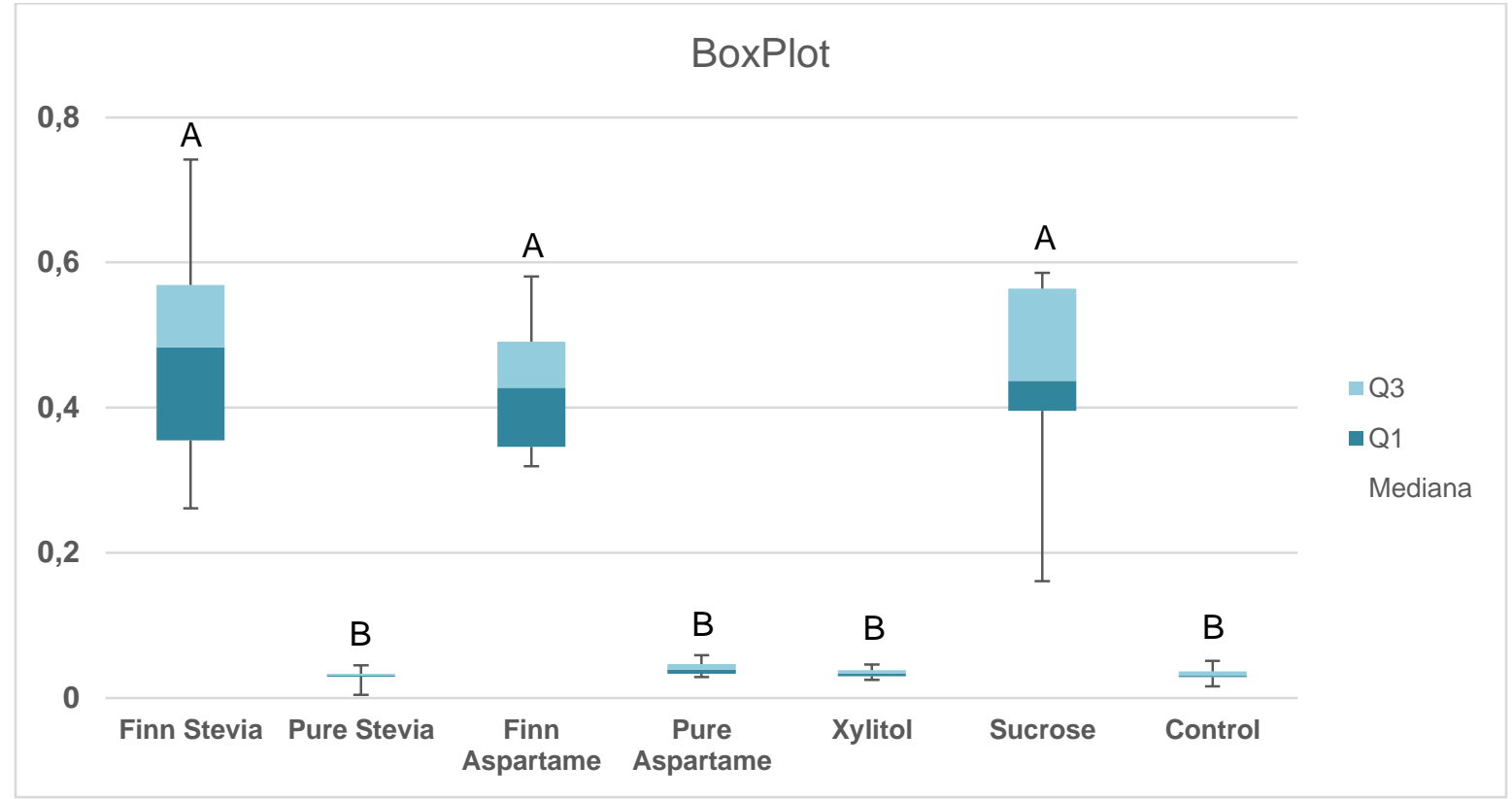

Figure 2. Box plot of lactic acid production analysis of the microcosm biofilm on enamel samples $(g / L)$. Kruskal-Wallis / Dunn $(p<0.0001) . n=12$. Different letters in the same column represent groups with significant differences 

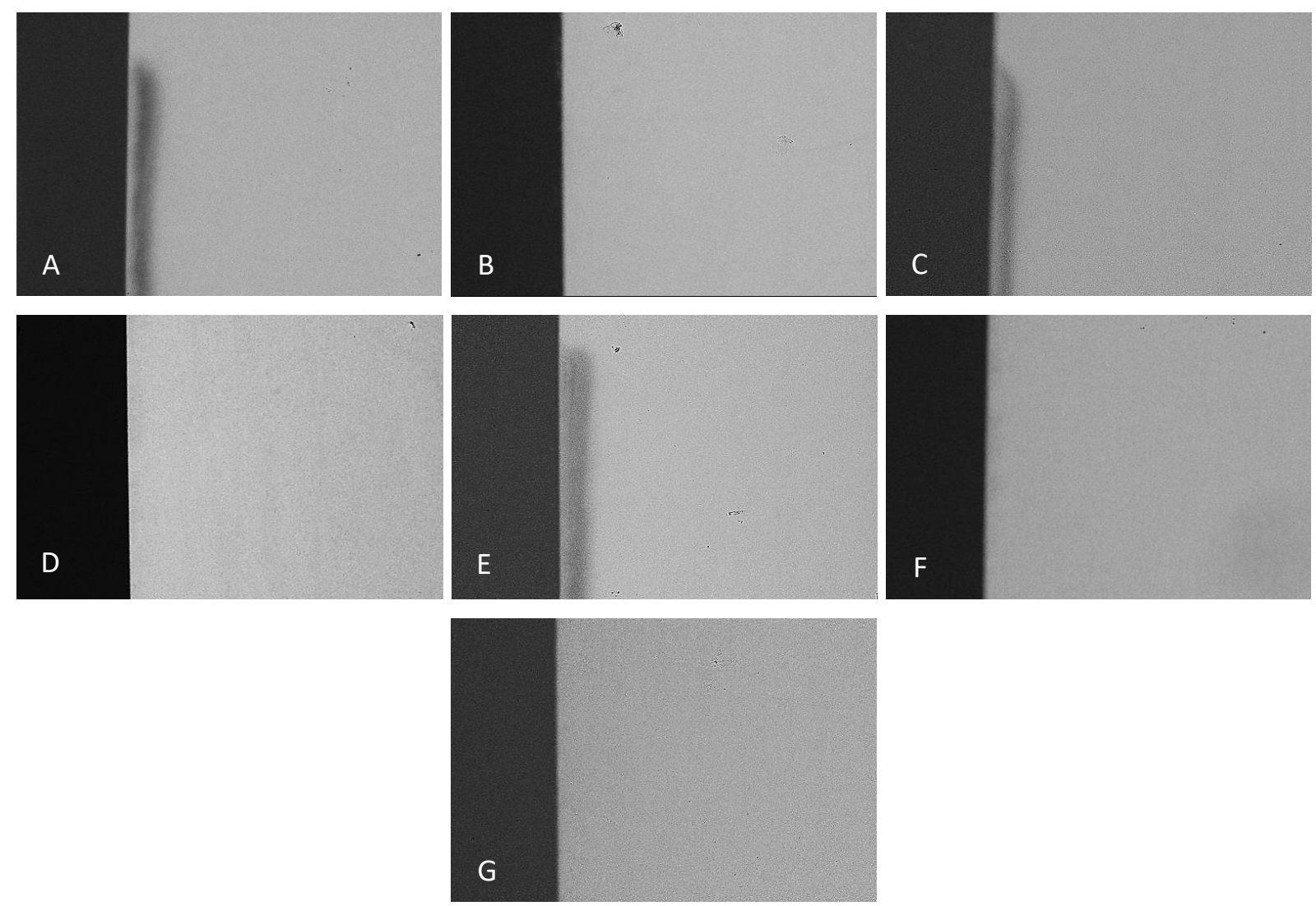

Figure 3. Representative images of TMR for enamel: A - stevia finn, B - pure stevia, C aspartame finn, D - pure aspartame, E - sucrose, F - xylitol, G - control. 


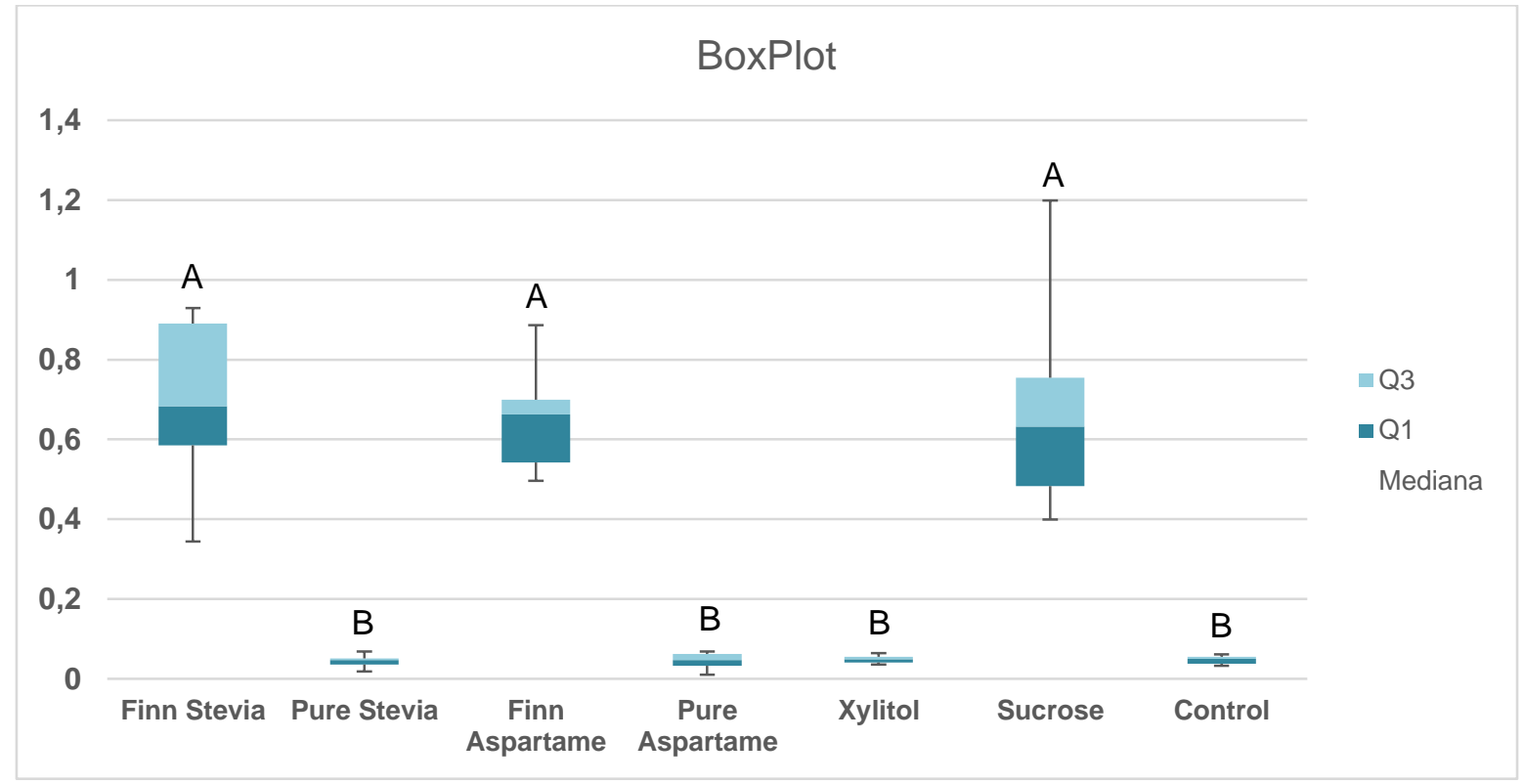

Figure 4. Box plot of lactic acid production analysis of the microcosm biofilm on dentin samples $(g / L)$. Kruskal-Wallis / Dunn $(p<0.0001)$. $n=12$. Different letters in the same column represent groups with significant differences. 

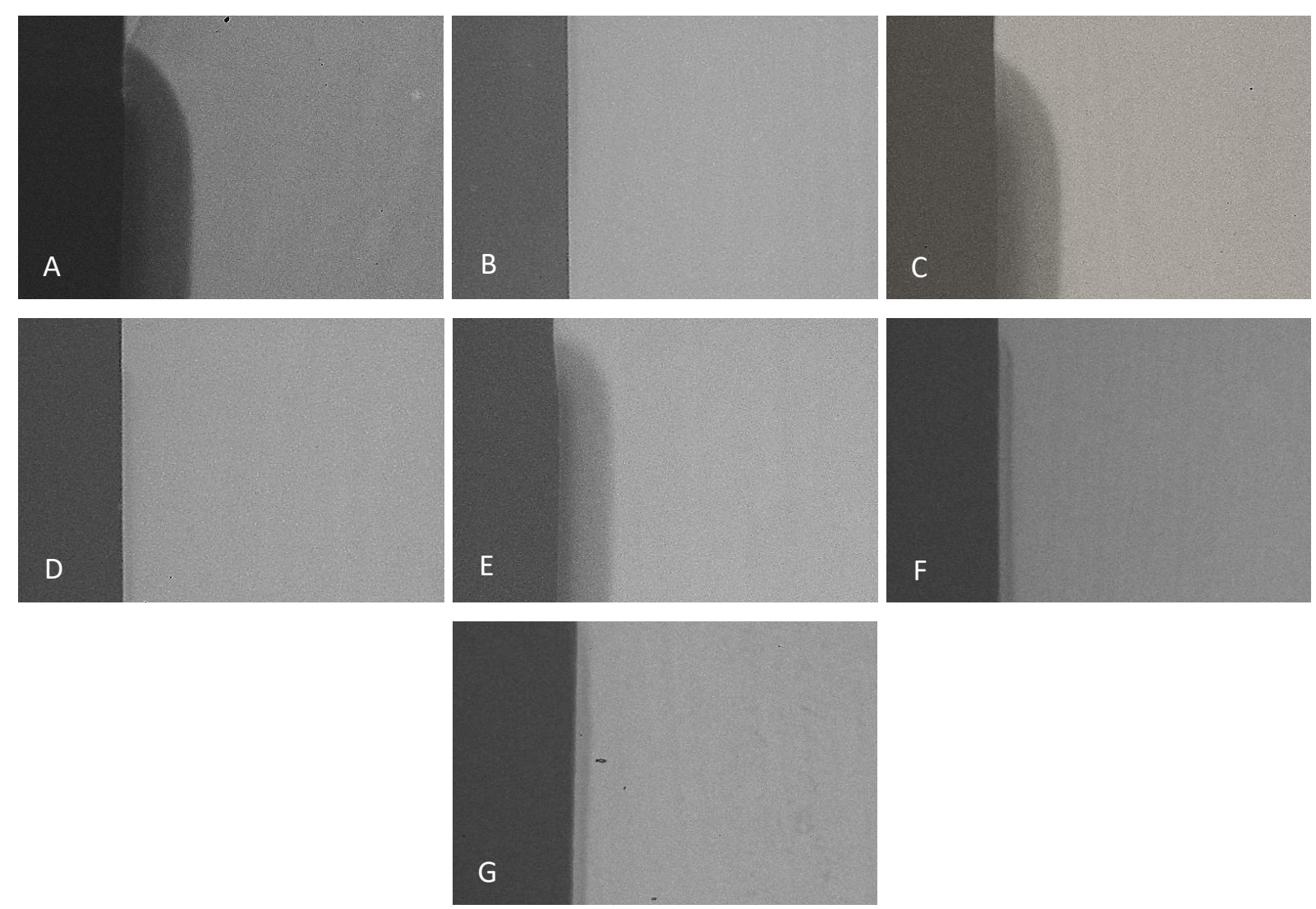

Figure 5. Representative images of TMR for dentin: A - stevia finn, B - pure stevia, C aspartame finn, D - pure aspartame, E - sucrose, F - xylitol, G - control. 

3 DISCUSSION 



\section{DISCUSSION}

The natural sweetener Stevia is considered one of the best substitutes for sucrose, as it is sweet, has low calories and no report of adverse effect (Contreras, 2013; Salvador-Reyes et al., 2014). The plant, from which this sweetener is obtained, is rich in carbohydrates, proteins, crude fiber, minerals $\left(\mathrm{K}^{+}, \mathrm{Ca}^{2+}, \mathrm{Na}^{+}, \mathrm{Mg}^{2+}, \mathrm{Cu}^{2+}\right.$, $\left.\mathrm{Mn}^{2+}, \mathrm{Fe}^{2+}, \mathrm{Zn}^{2+}\right)$ and essential amino acids. It has a high percentage of steviol (stevioside, steviolbioside, rebaudioside AF and dulcoside) (Escobar et al., 2020), which in turn has been responsible for its antimicrobial effect (Ferrazzano et al., 2015). However, its role in preventing caries and promoting oral health is not fully understood.

Steviosides offer several advantages over other non-caloric substitutes such as heat-stable, resistant to acid hydrolysis and they are non-fermentable (Giongo et al., 2014). The data suggest that steviol glycosides are not cariogenic and may have beneficial effects in preventing dental caries (Samuel et al., 2018).

Our work has shown that a commercial sweetener containing stevia is as cariogenic as sucrose, although some antimicrobial effect has been seen in the biofilm formed on dentin. Escobar et al. (2020) demonstrated that, even with the

presence of Stevia, S. mutans managed to metabolize sucrose and produce acids, being stevia ineffective in reducing microbial viability under sucrose exposure.

Part of Stevia's cariogenic effect, seen in our work, can be justified by the presence of lactose; being its concentration estimated in $94 \%$ This sugar may have been metabolized by the biofilm bacteria and caused caries. When there are two sources of energy supply (for example, stevia and lactose), bacteria can adapt to the conditions of the environment and metabolize one of the two sources of energy from which it obtains more energy (Aragão et al., 2019). Therefore, we decided to test the pure form of Stevia, whose results of lactic acid assay and TMR confirmed that the sweetener is not cariogenic and that the results found for the commercial product was due to the presence of lactose. We did not perform CFU counting in case of pure stevia and pure aspartame, since the results of the other methods were enough to show their non-cariogenic potential. 
A similar finding was seen for the commercial sweetener containing aspartame (and also lactose) in our work, which was as cariogenic as stevia and sucrose. Aspartame is a dipeptide ester (aspartic acid is attached to the $\mathrm{N}$-terminal portion of phenylalanine), presented as a white crystalline powder with a refreshing aroma and characteristic of a sweet flavor. In an aqueous solution, aspartame is about 160 times sweeter than sucrose (Matsukubo \& Takazoe, 2006).

According to Giacaman et al. (2013) using a monospecie biofilm (S. mutans), aspartame reduced the biofilm $\mathrm{pH}$ around 5.4 after $80 \mathrm{~h}$, value higher than that induced by sucrose, but very close to the critical $\mathrm{pH}$ for apatite. In the cited study, the biofilm exposed to stevia during this period had a $\mathrm{pH}$ of around 6.0 , value closed with what was found for Giongo et al. (2014) using 7\% stevioside and 93\% lactose. Regarding the biomass of the biofilm, all the sugars and sweeteners mentioned showed a high value compared to the control group $(\mathrm{NaCl})$. All sugars and sweeteners showed cariogenic potential, but lower than the sucrose. After 5 days of biofilm cultivation, enamel demineralization induced by fructose (30\% loss of microhardness), aspartame (approximately 23\%) and stevia (approximately 18\%) was significantly lower when compared to the positive control group (sucrose, approximately $43 \%$ ). In our study, the cariogenic potential of the commercial aspartame was due to the presence of lactose (94\%), which was proved by the lactic acid assay and TMR images of samples exposed to pure aspartame. Differently what was shown above, we found similarity between the commercial sweeteners and sucrose, which may be due to the experimental model (microcosm biofilm and continuous sweetener exposure for 5 days) and the response variable (TMR) applied in the present study.

Artificial sweeteners are usually hundreds of times sweeter than sucrose. In our study, we tested all groups at the same concentration, but in the real situation the amount of sweetener applied is much lower than sucrose. Products containing sweeteners, for this reason, cannot be sold in their pure form. For example, a tablet of a commercial product advertised as sucralose usually contains only about $10 \%$ sucralose with higher proportions of other carbohydrates, usually lactose, starch or starch hydrolysates (Giacaman et al., 2013). Although lactose is considered one of the least cariogenic sugars, evidence points out that repeated exposures to this carbohydrate can lead microorganisms (S. mutans) to adapt and to produce acids 
from lactose, more quickly over time (Hamilton \& Letbag, 1979; Birkhed et al., 1993; Zeng et al., 2010; Aragão et al., 2019).

As expected, xylitol (anti-cariogenic) and control (no supplementation) groups significantly reduced the number of microorganisms in biofilm. Xylitol (sugar alcohol of $5 \mathrm{C}$ ) is not easily metabolized by cariogenic microorganisms. The decrease in the biofilm $\mathrm{pH}$ caused by this sugar is not enough to induce enamel demineralization (Marghalani et al., 2017). Streptococcus mutans, a gram-positive bacteria identified as being primarily responsible for the caries process, do not metabolize xylitol for energy. Xylitol is transported into cells by the induced action of a fructose transporter, however, it causes a futile cycle because it is not going through to glycolytic reactions or, when accumulated, induces cell damage (Ly et al., 2008; Masoud et al., 2015; Riley et al., 2015). Xylitol is also known to improve remineralization of artificial caries lesions in vitro and in situ (Cardoso et al., 2014; Cardoso et al., 2016).

Future studies can be designed in order to understand the cariogenic potential of different pure and commercial sweeteners using models closer to the in vivo condition such as in situ models. With more scientific evidence, the population shall be advised about the different cariogenic potential among the sweeteners brand names.

In conclusion, commercial sweeteners containing stevia and aspartame (Finn trademark) demonstrated to be as cariogenic as sucrose in this experimental model, due to the presence of other components, since the pure forms of the sweeteners are not cariogenic. 




\section{REFERENCES}

Aragão MGB, Ricomini Filho AP, Cury JA. Adaptação de Streptococcus mutans à lactose, cariogenicidade do biofilme formado e desmineralização da dentina. Dissertação de Mestrado - Faculdade de Odontologia de Piracicaba, Universidade Estadual De Campinas. Campinas 2019.

Ayoub HM, Gregory RL, Tang Q, Lippert F. Influence of salivary conditioning and sucrose concentration on biofilm-mediated enamel demineralization. J Appl Oral Sci. 2020;28:e20190501.

Azad MB, Sharma AK, de Souza RJ, Dolinsky VW, Becker AB, Mandhane PJ, et al. Canadian healthy infant longitudinal development study Investigators. Association Between Artificially Sweetened Beverage Consumption During Pregnancy and Infant Body Mass Index. JAMA Pediatr. 2016 Jul 1;170(7):662-670.

Birkhed D, Imfeld T, Edwardsson S. pH changes in human dental plaque from lactose and milk before and after adaptation. Caries Res. 1993;27:43-50.

Bowen WH. Do we need to be concerned about dental caries in the coming millennium? Crit Oral Biol Med. 2002;13:126-131.

Cardoso CA, de Castilho AR, Salomao PM, Costa EN, Magalhaes AC, Buzalaf MA. Effect of xylitol varnishes on remineralization of artificial enamel caries lesions in vitro. J Dent. 2014;42:1495-1501.

Cardoso CA, Cassiano LP, Costa EN, Souza-E-Silva CM, Magalhães AC, Grizzo LT et al. Effect of xylitol varnishes on remineralization of artificial enamel caries lesions in situ. J Dent. 2016;50:74-78.

Ccahuana-Vásquez RA, Tabchoury CP, Tenuta LM, Del Bel Cury AA, Vale GC, Cury JA. Effect of frequency of sucrose exposure on dental biofilm composition and enamel demineralization in the presence of fluoride. Caries Res. 2007;41(1):9-15.

Contreras S. Anticariogenic properties and effects on periodontal structures of Stevia rebaudiana Bertoni. Narrative review. J Oral Res. 2013;2(3):158-166.

Escobar E, Piedrahita M, Gregory RL. Growth and viability of Streptococcus mutans in sucrose with different concentrations of Stevia rebaudiana Bertoni. Clin Oral Investig. 2020;24(9):3237-3242. 
Ferrazzano GF, Cantile T, Alcidi B, Coda M, Ingenito A, Zarrelli A et al. Is Stevia rebaudiana Bertoni a Non Cariogenic Sweetener? A Review. Molecules. 2015;21(1):E38.

Giacaman RA, Campos P, Muñoz-Sandoval C, Castro RJ. Cariogenic potential of commercial sweeteners in an experimental biofilm caries model on enamel. Arch Oral Biol. 2013;58(9):1116-1122.

Giacaman RA. Sugars and beyond. The role of sugars and the other nutrients and their potential impact on caries. Oral Dis. 2018;24(7):1185-1197.

Giongo FC, Mua B, Parolo CC, Carlén A, Maltz M. Effects of lactose-containing stevioside sweeteners on dental biofilm acidogenicity. Braz Oral Res. 2014;28:0026.

Hamilton IR, Lebtag H. Lactose metabolism by Streptococcus mutans: Evidence for induction of the tagatose 6-phosphate pathway. J Bacteriol. 1979;140(3):1102-1104.

Jayalath VH, de Souza RJ, Ha V, Mirrahimi A, Blanco-Mejia S, Di Buono M, et al. Sugar-sweetened beverage consumption and incident hypertension: a systematic review and meta-analysis of prospective cohorts. Am J Clin Nutr. 2015;102(4):914921.

Keyes $\mathrm{PH}$. The infectious and transmissible nature of experimental dental caries. Findings and implications. Arch Oral Biol. 1960;1:304-320.

Kishta OA, Derani M, Neiva GF, Boynton JR, Kim YE, Fontana M. The antimicrobial potential of stevia in an in vitro microbial caries model. Am J Dent. 2016;29(2):87-92.

Li J, Wu T, Peng W, Zhu Y. Effects of resveratrol on cariogenic virulence properties of Streptococcus mutans. BMC Microbiol. 2020;20(1):99.

Lohner S, Toews I, Meerpohl JJ. Health outcomes of non-nutritive sweeteners: analysis of the research landscape. Nutr J. 2017;16(1):55.

Ly KA, Milgrom $\mathrm{P}$, Rothen $\mathrm{M}$. The potential of dental-protective chewing gum in oral health interventions. JADA. 2008;139(5):553-563.

Ma MS, Blanksma NG. Stevia in the fight against dental caries. Ned Tijdschr Tandheelkd. 2015;122(1):51-55. 
Manios Y, Lambrinou CP, Mavrogianni C, Cardon G, Lindström J, lotova V, et al. Lifestyle Changes Observed among Adults Participating in a Family- and CommunityBased Intervention for Diabetes Prevention in Europe: The 1st Year Results of the Feel4Diabetes-Study. Nutrients. 2020;30;12(7):E1949.

Marghalani AA, Guinto E, Phan M, Dhar V, Tinanoff N. Effectiveness of Xylitol in Reducing Dental Caries in Children. Pediatr Dent. 2017;39(2):103-110.

Marro F, De Smedt S, Rajasekharan S, Martens L, Bottenberg P, Jacquet W. Associations between obesity, dental caries, erosive tooth wear and periodontal disease in adolescents: a case-control study. Eur Arch Paediatr Dent. 2021; 22(1):99-108.

Marsh PD, Moter A, Devine DA. Dental plaque biofilms: communities, conflict and control. Periodontol 2000. 2011;55:16-35.

Masoud MI, Allarakia R, Alamoudi NM, Nalliah R, Allareddy V. Long-term clinical and bacterial effects of xylitol on patients with fixed orthodontic appliances. Prog Orthod. 2015;16(35):18-20.

Matsukubo T, Takazoe I. Sucrose substitutes and their role in caries prevention. Int Dent J. 2006;56(3):119-130.

Momtazi-Borojeni AA, Esmaeili SA, Abdollahi E, Sahebkar A. A Review on the pharmacology and toxicology of steviolglycosides extracted from Stevia rebaudiana. Curr Pharm Des. 2017;23(11):1616-1622.

Moynihan P, Miller C. Beyond the Chair: Public Health and Governmental Measures to Tackle Sugar. J Dent Res. 2020;99(8):871-876.

Moynihan P. Sugars and dental caries: evidence for setting a recommended threshold for intake. Adv Nutr. 2016;7(1):149-156.

Nichol AD, Holle MJ, An R. Glycemic impact of non-nutritive sweeteners: a systematic review and meta-analysis of randomized controlled trials. Eur $\mathrm{J}$ Clin Nutr. 2018;72:796-804.

Paes Leme AF, Koo H, Bellato CM, Bedi G, Cury JA. The role of sucrose in cariogenic dental biofilm formation-new insight. J Dent Res. 2006;85(10):878-887.

Pitts NB, Zero DT, Marsh PD, Ekstrand K, Weintraub JA, Ramos-Gomez F, et al. Dental caries. Nat Rev Dis Primers. 2017;25(3):17030. 
Riley $\mathrm{P}$, Moore D, Ahmed F, Sharif MO, Worthington HV. Xylitol containing products for preventing dental caries in children and adults. Cochrane Database Syst Rev. 2015;26(3):CD010743.

Salvador-Reyes R, Sotelo-Herrera M, Paucar-Menacho L. Study of Stevia (Stevia rebaudiana Bertoni) as a natural sweetener and its use in benefit of the health. Scientia Agropecuaria. 2014;5(3):157-163.

Samuel P, Ayoob KT, Magnuson BA, Wölwer-Rieck U, Jeppesen PB, Rogers PJ, et al. Stevia Leaf to Stevia Sweetener: Exploring Its Science, Benefits, and Future Potential. J Nutr. 2018;148(7):1186S-1205S.

Santos PS, Caria CRP, Gotardo EMF, Ribeiro ML, Pedrazzoli J, Gambero A. Artificial sweetener saccharin disrupts intestinal epithelial cells' barrier function in vitro. Food Funct. 2018;9(7):3815-3822.

Tinanoff N, Holt K. Children's Sugar Consumption: Obesity and Dental Caries. Pediatr Dent. 2017;39(1):12-13.

Zeng L, Das S, Burne RA. Utilization of lactose and galactose by Streptococcus mutans: transport, toxicity, and carbon catabolite repression. J Bacteriol. 2010;192(9):2434-2444. 
APÊNDICE 



\section{APÊNDICE A- TERMO DE CONSENTIMENTO LIVRE E ESCLARECIDO}

Caro aluno de pós-graduação do Laboratório de Bioquímica da Faculdade de Odontologia de Bauru, através deste termo, Ihe convidamos para participar da pesquisa intitulada "Efeito do adoçante Stevia sobre o desenvolvimento da cárie dentária em esmalte e dentina sob um modelo de biofilme microcosmo". A nossa pesquisa tem como objetivo comparar o efeito do Stevia (adoçante natural) a do aspartame (adoçante sintético), da sacarose e do xilitol sobre o desenvolvimento da cárie dentária em um modelo de biofilme microcosmo em esmalte e dentina, o qual será conduzido no laboratório. Para isso, gostaríamos de solicitar a doação de sua saliva, para que possamos ter as bactérias bucais necessárias para a formação do biofilme no laboratório. Esta pesquisa será feita por mim (Ana Carolina Magalhães) com colaboração dos pesquisadores Luiz Ricardo Pero Vecchia, Aline Silva, Carolina Ruis Ferrari, Beatriz Martines de Souza, e Rafaela Ricci Kim.

É importante destacar que de acordo com o item IV.6.b da resolução 466/12 você terá garantida a liberdade do consentimento para a participação ou não na pesquisa, sem qualquer represália. Portanto, garantimos que não será coagido e nem sofrerá restrições de suas atividades usuais na FOB/USP.

Anteriormente à coleta de saliva, você será submetido a uma avaliação da sua condição bucal e a algumas perguntas para verificarmos se você se enquadra dentro dos critérios de inclusão da pesquisa: ter histórico de lesões cariosas mas não ser cárie ativo (apresentar lesões de mancha branca ativa ou lesões cavitadas), não apresentar sinais de gengivite/periodontite (presença de sangramento e mobilidade dentária) e não ter ingerido antibióticos nos últimos 3 meses. Lactantes, gestantes, fumantes e indivíduos com doenças crônicas serão automaticamente excluídos da amostra.

Uma vez selecionado, ficará combinado que você deverá não escovar os dentes por $24 \mathrm{~h}$ assim como ficar em jejum (comida e água) $2 \mathrm{~h}$ anteriores à coleta da saliva. A saliva será coletada no período da manhã, por volta das 9-10h, em uma data a ser agendada. A saliva será coletada sob estimulo por mastigação de uma parafina plástica- Parafilm (que é uma película plástica, sem cheiro, sem cor, resistente à água) durante 10 minutos. Durante este período, você cuspirá toda a saliva em um recipiente plástico. O objetivo desta estimulação de saliva é aumentar a quantidade de saliva produzida para termos volume de amostra suficiente. 
Aproveitaremos a oportunidade e mensuraremos o seu fluxo salivar, o que também está dentro do critério de inclusão da pesquisa, e lhe informaremos se ele está adequado ou não.

A sua participação neste trabalho acarretará em risco mínimo, que acontecerá no caso de você ter alergia ao plástico utilizado para mastigação ou se você apresentar enjoos na hora da coleta. Nestes casos, você deverá comunicar o responsável pela pesquisa, que estará presente no momento da coleta, o qual o(a) liberará da participação na pesquisa, sem penalização alguma. Ainda ressaltamos que o fato de ficar 24 h sem escovar os dentes não acarretará prejuízos a sua saúde bucal.

Os gastos que forem gerados por este trabalho ficarão a cargo da responsável pelo projeto. Importante ressaltar que não está sendo considerado nenhum pagamento ou recompensa material pela sua participação neste estudo. Você terá garantido o direito à indenização compensatória caso fique comprovado que a sua participação acarretou algum problema a você. É importante destacar que como benefício direto, logo após a coleta, você terá direito a uma profilaxia profissional e a um lanche.

Você não precisará passar por nenhum outro tipo de procedimento adicional. Isso quer dizer que utilizaremos apenas a saliva. Queremos deixar claro que não existe a menor obrigação de você doar saliva para a pesquisa. Isso é totalmente voluntário. A saliva doada que não for usada na pesquisa será descartada no lixo contaminado do laboratório de Bioquímica.

Esta pesquisa gerará como benefício indireto um maior conhecimento sobre o efeito do adoçante Stevia no desenvolvimento da cárie dentária em esmalte e dentina, o que poderá em longo prazo gerar novos produtos que poderão auxiliar na prevenção desta doença bucal.

Você pode recusar-se em assinar este termo para a não participação na pesquisa e mesmo após assinar este termo, caso mude de idéia e queira retirar seu consentimento em qualquer fase da pesquisa, poderá fazê-lo sem nenhuma represália. Todo o trabalho será feito sem a sua identificação, preservando completamente sua identidade. Ao concordar em participar desta pesquisa, você receberá uma via igualmente válida deste termo. O direito à indenização lhe será permitido, caso ocorra algum dano decorrente da sua participação nesta pesquisa. Caso necessite de ajuda financeira para participar desta pesquisa (no caso, 
transporte da sua residência à FOB e vice-versa, para a coleta de saliva) ela poderá ser ressarcida pelo pesquisador.

Qualquer dúvida ou maiores esclarecimentos você poderá recorrer a qualquer um dos membros da equipe do projeto (Laboratório de Bioquímica 14-3235-8247) ou a pesquisadora responsável Ana Carolina Magalhães (telefone 14 / 98118-9106, email acm@usp.br). Caso possua preocupações quanto aos seus direitos como participante deste estudo, ou queira fazer denúncias quanto à condução do mesmo, sinta-se a vontade para procurar o Comitê de Ética em Pesquisa, da Faculdade de Odontologia de Bauru/USP, Alameda Dr. Octávio Pinheiro Brisolla, 9-75, telefone (14)3235-8356 ou e-mail: cep@fob.usp.br e a forma de contato com CONEP Endereço: Esplanada dos Ministérios, Bloco G, Anexo B. Sala 104B, telefone: (61) 3315-5878, e-mail: cns@saude.gov.br. 


\section{TERMO DE CONSENTIMENTO LIVRE E ESCLARECIDO}

Pelo presente instrumento que atende às exigências legais, o Sr. (a) , portador da cédula de identidade , após leitura minuciosa das informações constantes neste TERMO DE CONSENTIMENTO LIVRE E ESCLARECIDO, devidamente explicada pelos profissionais em seus mínimos detalhes, ciente dos serviços e procedimentos aos quais será submetido, não restando quaisquer dúvidas a respeito do lido e explicado, DECLARA e FIRMA seu CONSENTIMENTO LIVRE E ESCLARECIDO concordando em participar da pesquisa proposta. Fica claro que o participante da pesquisa, pode a qualquer momento retirar seu CONSENTIMENTO LIVRE E ESCLARECIDO e deixar de participar desta pesquisa e ciente de que todas as informações prestadas tornar-seão confidenciais e guardadas por força de sigilo profissional (Art. 9ํำ do Código de Ética Odontológica).

Por fim, como pesquisador(a) responsável pela pesquisa, DECLARO o cumprimento do disposto na Resolução CNS no 466 de 2012, contidos nos itens IV.3, item IV.5.a e na íntegra com a resolução CNS no 466 de dezembro de 2012.

Por estarmos de acordo com o presente termo o firmamos em duas vias igualmente válidas (uma via para o participante da pesquisa e outra para o pesquisador) que serão rubricadas em todas as suas páginas e assinadas ao seu término, conforme o disposto pela Resolução CNS no 466 de 2012, itens IV.3.f e IV.5.d.

Bauru, SP, de de 
O Comitê de Ética em Pesquisa - CEP, organizado e criado pela FOB-USP, em 29/06/98 (Portaria GD/0698/FOB), previsto no item VII da Resolução no 466/12 do Conselho Nacional de Saúde do Ministério da Saúde (publicada no DOU de 13/06/2013), é um Colegiado interdisciplinar e independente, de relevância pública, de caráter consultivo, deliberativo e educativo, criado para defender os interesses dos participantes da pesquisa em sua integridade e dignidade e para contribuir no desenvolvimento da pesquisa dentro de padrões éticos.

Qualquer denúncia e/ou reclamação sobre sua participação na pesquisa poderá ser reportada a este CEP:

Horário e local de funcionamento:

Comitê de Ética em Pesquisa

Faculdade de Odontologia de Bauru-USP - Prédio da Pós-Graduação (bloco E pavimento superior), de segunda à sexta-feira, no horário das 14 hs às 17 horas, em dias úteis.

Alameda Dr. Octávio Pinheiro Brisolla, 9-75

Vila Universitária - Bauru - SP - CEP 17012-901

Telefone/FAX(14)3235-8356

e-mail: cep@fob.usp.br 

AnEXOS 

ANEXO A - Parecer Consubstanciado do CEP

\section{PARECER CONSUBSTANCIADO DO CEP}

\section{DADOS DO PROJETO DE PESQUISA}

Título da Pesquisa: Efeito do adoçante Stevia sobre o desenvolvimento da cárie dentária

Pesquisador: Ana Carolina Magalhães

Área Temática:

Versão: 1

CAAE: 12647819.5 .0000 .5417

Instituição Proponente: Universidade de Sao Paulo

Patrocinador Principal: FUNDACAO DE AMPARO A PESQUISA DO ESTADO DE SAO PAULO

\section{DADOS DO PARECER}

Número do Parecer: 3.325.154

Apresentação do Projeto:

É um estudo de análise do efeito do adoçante Stevia sobre o desenvolvimento da cárie dentária em esmalte e dentina sob um modelo de biofilme microcosmo.

Objetivo da Pesquisa:

O objetivo do projeto será comparar o efeito do Stevia (adoçante natural) ao do aspartame (adoçante sintético), da sacarose e do xilitol sobre o desenvolvimento da cárie dentária em um modelo de biofilme microcosmo em esmalte e dentina.

\section{Avaliação dos Riscos e Beneficios:}

Risco mínimo, relacionado a coleta de saliva dos participantes.

Os benefícios são relacionados à melhor compreensão dos efeitos da Stevia em relação às condições de cariogenicidade na cavidade bucal.

Comentários e Considerações sobre a Pesquisa:

Pesquisa relevante de alto potencial de contribuição para o avanço do conhecimento na área.

Considerações sobre os Termos de apresentação obrigatória:

Todos os termos foram apresentados em conformidade com as normas éticas.

Recomendações:

Não há 
Conclusões ou Pendências e Lista de Inadequações:

Aprovado sem pendências.

Consideraçöes Finais a critério do CEP:

Esse projeto foi considerado APROVADO na reunião ordinária do CEP de 08/05/2019, com base nas normas éticas da Resolução CNS 466/12. Ao término da pesquisa o CEP-FOB/USP exige a apresentação de relatório final. Os relatórios parciais deverão estar de acordo com o cronograma e/ou parecer emitido pelo CEP. Alterações na metodologia, título, inclusão ou exclusão de autores, cronograma e quaisquer outras mudanças que sejam significativas deverão ser previamente comunicadas a este CEP sob risco de não aprovação do relatório final. Quando da apresentação deste, deverão ser incluídos todos os TCLEs e/ou termos de doação assinados e rubricados, se pertinentes.

Este parecer foi elaborado baseado nos documentos abaixo relacionados:

\begin{tabular}{|c|c|c|c|c|}
\hline Tipo Documento & Arquivo & Postagem & Autor & Situação \\
\hline $\begin{array}{l}\text { Informações Básicas } \\
\text { do Projeto }\end{array}$ & $\begin{array}{l}\text { PB_INFORMAÇŐES_BÁSICAS_DO_P } \\
\text { ROJETO_1321923.pdf }\end{array}$ & $\begin{array}{c}18 / 04 / 2019 \\
11: 25: 47\end{array}$ & & Aceito \\
\hline Outros & \begin{tabular}{|l|l|} 
termo_de_aquiescencia_departamento.p \\
df
\end{tabular} & $\begin{array}{c}18 / 04 / 2019 \\
11: 19: 51 \\
\end{array}$ & \begin{tabular}{|l|} 
LUIZ RICARDO \\
PERO VECCHIA \\
\end{tabular} & Aceito \\
\hline $\begin{array}{l}\text { Projeto Detalhado / } \\
\text { Brochura } \\
\text { Investigador }\end{array}$ & projeto_de_pesquisa.docx & $\begin{array}{c}17 / 04 / 2019 \\
19: 59: 21\end{array}$ & $\begin{array}{l}\text { LUIZ RICARDO } \\
\text { PERO VECCHIA }\end{array}$ & Aceito \\
\hline $\begin{array}{l}\text { TCLE / Termos de } \\
\text { Assentimento / } \\
\text { Justificativa de } \\
\text { Ausência }\end{array}$ & TCLE.doc & $\begin{array}{c}17 / 04 / 2019 \\
19: 19: 36\end{array}$ & $\begin{array}{l}\text { LUIZ RICARDO } \\
\text { PERO VECCHIA }\end{array}$ & Aceito \\
\hline $\begin{array}{l}\text { Declaração do } \\
\text { Patrocinador }\end{array}$ & termo_de_outorga_fapesp.pdf & $\begin{array}{c}17 / 04 / 2019 \\
18: 44: 23\end{array}$ & $\begin{array}{l}\text { LUIZ RICARDO } \\
\text { PERO VECCHIA }\end{array}$ & Aceito \\
\hline $\begin{array}{l}\text { Declaração de } \\
\text { Pesquisadores }\end{array}$ & $\begin{array}{l}\text { DECLARACAO_DE_COMPROMISSO_ } \\
\text { DO_PESQUISADOR_COM_RESULTAD } \\
\text { OS.pdf }\end{array}$ & $\begin{array}{c}17 / 04 / 2019 \\
18: 39: 44\end{array}$ & $\begin{array}{l}\text { LUIZ RICARDO } \\
\text { PERO VECCHIA }\end{array}$ & Aceito \\
\hline Outros & CEP_ANIMAL.pdf & $\begin{array}{c}17 / 04 / 2019 \\
18: 37: 28 \\
\end{array}$ & $\begin{array}{l}\text { LUIZ RICARDO } \\
\text { PERO VECCHIA }\end{array}$ & Aceito \\
\hline Outros & termo_de_AquiescenciaCIP.pdf & $\begin{array}{c}17 / 04 / 2019 \\
18: 36: 35 \\
\end{array}$ & $\begin{array}{l}\text { LUIZ RICARDO } \\
\text { PERO VECCHIA }\end{array}$ & Aceito \\
\hline Outros & $\begin{array}{l}\begin{array}{l}\text { termo_de_Aquiescencia_posgraduacao. } \\
\text { pdf }\end{array} \\
\end{array}$ & $\begin{array}{c}17 / 04 / 2019 \\
18: 34: 59 \\
\end{array}$ & \begin{tabular}{|l|} 
LUIZ RICARDO \\
PERO VECCHIA \\
\end{tabular} & Aceito \\
\hline Outros & QUESTIONARIO_TECNICO_PDF.pdf & $\begin{array}{c}17 / 04 / 2019 \\
17: 59: 20 \\
\end{array}$ & $\begin{array}{l}\text { LUIZ RICARDO } \\
\text { PERO VECCHIA }\end{array}$ & Aceito \\
\hline Folha de Rosto & Untitled_20190416_140833.pdf & $17 / 04 / 2019$ & LUIZ RICARDO & Aceito \\
\hline
\end{tabular}




\section{USP - FACULDADE DE ODONTOLOGIA DE BAURU DA QReraril
USP}

Contnuaçăo do Parecer. 3.325.154

\begin{tabular}{|l|l|l|l|l|}
\hline Folha de Rosto & Untitled_20190416_140833.pdf & $16: 24: 19$ & PERO VECCHIA & Aceito \\
\hline
\end{tabular}

Situação do Parecer:

Aprovado

Necessita Apreciação da CONEP:

Não

BAURU, 14 de Maio de 2019

Assinado por:

Ana Lúcia Pompéia Fraga de Almeida

(Coordenador(a)) 


\section{Universidade de São Paulo Faculdade de Odontologia de Bauru}

Comissāo de Ética no Uso de Animais

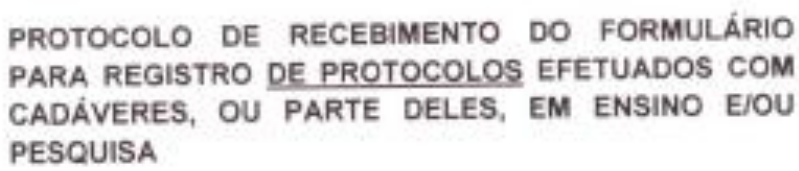

PROTOCOLO DE RECEBIMENTO DO FORMULÁRIO PARA REGISTRO DE PROTOCOLOS EFETUADOS COM CADÁVERES, OU PARTE DELES, EM ENSINO EIOU PESQUISA

Finalidade:

Periodo:

Título da pesquisa:

Pesquisador Responsável:

Pesquisador Executor:

Colaboradores:

Ricci Kim

Nota Fiscal/Termo de Doação Termo de Doaçăo-Frigol (incluido possiveis perdas)

N Lote / Data do Abate $5 / 02 / 04 / 2019$

$N^{\circ}$ utilizados $/ N^{\circ}$ de grupos:

5 grupos - total utilizado 216

\section{Pesquisa}

Mar/2019a Fev/2019

Efeito do adoçante Stevia sobre o desenvolvimento da cárie dentária em esmalte e dentina sob um modelo de biofilme microcosmo

Profa. Dra. Ana Carolina Magalhăes

Luiz Ricardo Pero Vecchia

Aline Silva Braga، Beatriz Martines de Souza, Carolina Ruis Ferrari e Ratela

Total adquirido: 300 dentes bovinos

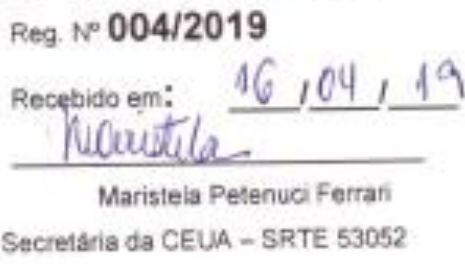

2




\section{ANEXO B - E-mail de submissão}

Fwd: CRE-2021-5-14 Manuscript submission confirmation

AM Ana Carolina Magalhães < acm@fob.usp.br>

09:13

Para: Caren Augustinho

Forwarded message

De: Caries Research <cre@manuscriptmanager.net>

Date: sex., 28 de mai. de 2021 às 09:12

Subject: CRE-2021-5-14 Manuscript submission confirmation

To: <acm@fob.usp.br>

Submission: CRE-2021-5-14 - Effect of sweetener containing stevia on the development of dental caries in enamel and dentin under a microcosm biofilm mode Submitting author: Prof Ana Magalhães

Attention: Prof Magalhães

Thank you very much for submitting the above manuscript. Please use the manuscript number as listed above on all correspondence about the manuscript.

The manuscript will now be forwarded to our reviewers and we shall inform you as soon as a decision has been made by the editorial board.

The progress of your manuscript can be followed from the progress report accessed from your account overview.

Kind regards,

Editorial Office 